\title{
NOTES
}

\section{The Indigent's Right to Counsel and the Rule of Prejudicial Error}

The Sixth Amendment to the Constitution provides that the accused in a criminal case shall have the right to "the Assistance of Counsel for his defence." In a discussion of this right, it is necessary to distinguish between the right of an accused to be represented by counsel whom he has retained, and the right of an indigent to have representation at state expense. A $A^{2}$ the time of the adoption of the Constitution, the right of representation was well established in the United States, although current English practice denied the right in any felony except treason. ${ }^{1}$ Until recent time, however, "right to counsel" provisions in the federal and state constitutions were not interpreted to award an indigent the right to appointed counsel, although certain early statutes gave such a right in capital cases. ${ }^{2}$ In the past two decades, the Supreme Court has handed down numerous decisions on the issue of an indigent's right to court-appointed counsel in capital and noncapital cases arising in the state and federal courts. As will be indicated in the discussion to follow, the decisions are somewhat conflicting, and have not yet coalesced into a definitive rule. Nonetheless, from the mass of decisions and statutes, there emerges an amorphous standard of the situations in which the accused has a right to court-appointed counsel. The procedural obstacles facing an indigent seeking to vindicate his right, and the effect of a finding of infringement have been of paramount importance in shaping the existing standard, and will have great influence in directing the future trend of the law upon a question which, in view of the large number of persons facing trial who are indigent, is far from academic. ${ }^{3}$

\section{The Rule in the Federal Courts}

Since 1790 , when Congress enacted a statute to that effect, ${ }^{4}$ a duty has been imposed upon the federal courts to appoint counsel in every capital case where the accused was not otherwise represented. Although federal judges had frequently furnished counsel to indigents faced with noncapital charges, appointment had not been established as a matter of right, ${ }^{5}$ until, in 1938, the leading case of Johnson v. Zerbst ${ }^{6}$ entailed a reconsideration of the problem. The defendant, who had neither requested nor been furnished wth counsel at his trial for a noncapital offense in federal district court, filed a petition for habeas corpus, alleging that the failure of that court to appoint counsel to represent him was a denial of his rights under the Sixth Amendment. In sustaining his contention, the Supreme Court held that every indigent defendant on trial in a federal court has the right to court-appointed counsel, unless he has competently and intelligently waived that right. This requirement

1. 5 Holdsworth, History of ENGLish LAW 192 (3d ed. 1945).

2. 1 Stat. $118(1790)$. This provision now appears as 18 U. S. C. $\$ 3005$ (Cong. Serv. 1948). For a listing of early state statutes covering the indigent's right to counsel, see Betts v. Brady, 316 U. S. 455, 467 (1942).

3. See Moley, Our Criminal Courts 62 et seq. (1930).

4. See note 2 supra.

5. See Bute v. Illinois, 333 U. S. 640,661 (1948); Holtzoff, The Right of Counsel Under the Sixth Amendment, 20 N. Y. U. L. Q. REv. 1, 8 (1944).

6. 304 U. S. 458 (1938). 
was forthwith enacted into the Federal Rules of Criminal Procedure. ${ }^{7}$ Since 1938, the only important question arising from federal trials has been whether, in fact as well as form, the accused waived his right to appointment. ${ }^{8}$

\section{The Indigent's Federal Rights in State Courts}

The extent to which state courts must appoint counsel to comply with the Federal Constitution is a presently unsettled area of the law. Since the guarantees of the Bill of Rights are per se applicable only to the Federal Government, ${ }^{9}$ it is clear that the petitioner claiming a violation of his constitutional rights must do so through the Fourteenth Amendment. Until 1932, the Supreme Court had given little consideration to the indigent's right to counsel in the state courts. In that year, a judicial milepost was reached in the leading case of Pozvell $v$. Alabama. ${ }^{10}$ Nine indigent Negro youths were indicted for rape, a capital offense in Alabama. Unrepresented at the trial, they were convicted, and sentenced to death; the Supreme Court granted certiorari. After an exhaustive consideration of the issue, the Court held that when an indigent faces a capital charge, due process of law requires the state court to furnish him with counsel. Since that time, numerous cases where the petitioner alleged conviction of a capital offense without the assistance of counsel have been presented to the Court. In only one instance where the allegations were supported by proof did the Court fail to find a violation of due process, and in that case the common law record recited a waiver of the right. ${ }^{11}$

Although the Supreme Court took pains to limit the rule of the Powell case to a situation involving a capital charge, contemporary observers were of the opinion that the right would be extended to noncapital crimes. Nevertheless, ten years later, in Betts $v$. Brady, ${ }^{12}$ the Court held that due process of law did not impose an absolute requirement upon state courts to appoint counsel for indigents charged with noncapital offenses. The dissent by Mr. Justice Black foreshadowed the views of a large dissenting minority at present consisting of Justices Black, Douglas, Murphy, and Rutledge. The divergent opinions in this case are of extreme importance in that they lay bare the fundamental disagreement which, to this day, divides the Court. The majority, after answering in the negative the hotly contested question whether the Fourteenth Amendment imposed the mandates of the Bill of Rights upon the states, went on to say that, in certain noncapital cases, a failure to furnish the indigent with counsel may constitute a deprivation of due process in that the defendant was prejudiced by lack of representation.

7. FED. R. CRIM. P., 44.

8. Where an intelligent defendant insists on conducting his own defense, it is not error to permit him to do so. Adams v. United States ex rel. McCann, 317 U. S. 269 (1942). But where the defendant is not made fully cognizant of her right to appointment, and does not exercise an intelligent choice, there is no waiver. Von Moltke v. Gillies, 332 U. S. 708 (1948) ; accord, Handlovits v. Adcock, 80 F. Supp. 425 (E. D. Mich. 1948).

9. Barron v. Baltimore, 7 Pet. 243 (U. S. 1833).

10. 287 U. S. 45 (1932).

11. Carter v. Illinois, 329 U. S. 173 (1946). The common law record which formed the sole basis for review was not clear as to whether the indigent had intelligently waived counsel, or whether he had merely failed to request appointment-the Court presumed regularity.

12. 316 U. S. 455 (1942). 
In other cases, such as that before the Court, a fair trial was possible even though the accused stood alone. The minority took the position that the Bill of Rights had been incorporated into the Fourteenth Amendment, and that the state could not infringe upon any provision in the former without violating the due process clause of the latter. In this manner, the minority applied the right to counsel provision of the Sixth Amendment to state trials. ${ }^{13}$ As an alternative ground for their decision that the petitioner's constitutional rights had been violated, the minority implied that the "fair trial" required by the due process clause was in no case possible where the defendant was unrepresented. ${ }^{14}$ Since 1942 , the majority rationale has held sway, and the decision as to the alleged denial of due process has turned on the majority justices' opinion as to whether the particular case before them reveals that the accused was prejudiced by a lack of representation.15

An analysis of the decisions is complicated by the majority's use of the term prejudice in two different connotations. In the bulk of the cases, by prejudice, they have meant that because of the accused's traits, or the nature of the crime, the possibility of prejudice stemming from the failure to appoint was so great that actual prejudice would be presumed. In a small number of the cases, the petitioner alleged actual prejudice resulting from a failure to appoint counsel, and if his contention was sustained, the majority used prejudice in the conventional sense. This distinction in terminology should be borne in mind when considering the factual situations which the Supreme Court has accepted or rejected as special circumstances under which a failure to appoint counsel deprived the accused of his constitutional rights.

Youth and Inexperience.-A large number of the cases coming before the Court on the issue of denial of counsel involve minor defendants. In a recent decision, Uveges v. Pennsylvania, ${ }^{16}$ a seventeen-yearold defendant, unrepresented by counsel, pleaded guilty to a charge of burglary. In voiding the conviction, the Court laid stress upon the belief that a person of such tender years could not adequately defend himself, and that lack of counsel was therefore prejudicial. Previous cases have likewise indicated that the Court will not suffer an unrepresented minor's conviction to stand. ${ }^{17}$ A related factor-that of intelligence and familiarity with courtroom procedure-has bulked large in a finding that failure to appoint was prejudicial. Where the record indicated that the accused was possessed of sufficient intelligence to safeguard his own interests, and that his previous trials had given him sufficient legal knowledge to conduct his own defense, appointed counsel has been held unnecessary to a

13. A discussion of the merits of the two positions is beyond the scope of this Note since the issue reaches into the broad field of the relationship between state and federal government. For a lucid presentation of the majority and minority views on this controversial question, see Adamson v. California, 332 U. S. 46 (1947).

14. This view is underscored by the fact that in every case since 1942 wherein the majority decided that a failure to appoint counsel had not violated the due process clause, there has been a dissenting opinion criticizing the fairness of the trial. See, e. g., Bute v. Illinois, 333 U. S. 640, 682 (1948) (dissenting opinion) ; Foster v. Illinois, 332 U. S. 134, 141 (1947) (dissenting opinion).

15. See Betts v. Brady, 316 U. S. 455, 472 (1942).

16. 335 U. S. 437 (1948).

17. Wade v. Mayo, 334 U. S. 672 (1948) (18-year-old defendant); De Meerleer v. Michigan, 329 U. S. 663 (1947) (17-year-old defendant). But cf. Canizio v. New York, 327 U. S. 82 (1946). 
fair trial. ${ }^{18}$ On the other hand, the Court has found prejudicial error in the failure to appoint counsel for an alien indigent whose knowledge of English was slight, and of court procedure, nil. ${ }^{19}$

Complexity of Issues.-The theory that counsel is not essential to the fairness of every trial is grounded on the assumption that a reasonably intelligent layman can, in many cases, prepare and plead an adequate defense pro se. In Betts $v$. Brady, the only issue presented was an alleged alibi, and this, the Court said, did not require counsel to insure adequate presentation. In Rice $v$. Olson, ${ }^{20}$ the unrepresented indigent was able to demonstrate that he had a valid jurisdictional defense which would only have been apparent to the trained practitioner. Although the Court set forth the general proposition that a complex case requires the àssistance of counsel, the issue appears to have been decided in the petitioner's favor because of his showing of actual prejudice.

The Court is divided on the question of what constitutes a complex issue. For example, in Bute v. Illinois, ${ }^{21}$ the majority felt that the defenses to a charge of taking indecent liberties with children could be presented by the defendant pro se. The four dissenting justices maintained that, even accepting the special circumstances test propounded by the majority, the case before them was one requiring professional advice and assistance, and that prejudice should therefore be presumed. ${ }^{22}$

Error of Court or Trickery of Prosecution.-The rationale for the long-obsolete rule that the accused had no right to be represented by counsel of his choice was that the trial court would protect his interests. ${ }^{23}$ Vestiges of this theory lurk in the background of the majority view which denies a universal right to court-appointed counsel. ${ }^{24}$ Where the trial court itself prejudices the accused, this rationale is patently inapplicable, and the Supreme Court has on occasion found a denial of due process. In Townsend $v$. Burke, ${ }^{25}$ the trial court misread the accused's record of prior convictions and apparently imposed a discretionary sentence on the basis of this misunderstanding. In reversing the conviction, the Court laid heavy emphasis upon this error as actual prejudice which would not have resulted had the accused been represented. However, in Gryger v. Burke, ${ }^{26}$ decided the same day, the conviction was affirmed, although the record clearly indicated that the trial judge erroneously interpreted as mandatory the life sentence which he meted out to the unrepresented defendant. These two cases present no factual differences to justify findings that lack of counsel was in fact prejudicial to Townsend, but not to Gryger, and one is strongly drawn to the conclusion of the four dissenting justices in the Gryger case that inconsistent decisions are the inevitable product of a subjective case-by-case determination as to whether the failure to appoint was prejudicial. ${ }^{27}$

18. See Betts v. Brady, 316 U. S. 455,472 (1942).

19. Marino v. Ragen, 332 U. S. 561 (1947).

20. 324 U. S. 786 (1945).

21. 333 U. S. 640 (1948).

22. For a typical example of judicial dispute as to whether a given case presented complex issues, see Foster v. Illinois, 332 U. S. 134 (1947).

23. Co. INST. $3 \mathrm{~d} * 29$.

24. Bute v. Illinois, 333 U. S. 640, 671 (1948) (presumption that the trial court has safeguarded defendant's interests). But cf. Powell v. Alabama, 287 U. S. 45, 61 (1932) (trial court not in a position to offer complete protection to defendant).

25. 334 U. S. 736 (1948).

26. 334 U. S. 728 (1948).

27. Id. at 736 (dissenting opinion). 
When the prosecutor becomes a persecutor, and tricks or misleads the unrepresented indigent into a prejudicial position, the Court takes the view that failure to appoint counsel was a denial of due process. In Smith v. O'Grady, ${ }^{28}$ the unrepresented defendant waived his right to trial in reliance upon the district attorney's assurance that he would receive a light sentence; instead, he received the maximum. In voiding the conviction, the Supreme Court pointed out that a desire to prevent such victimization was one of the main reasons for giving an accused the right to counsel.

Noninfluential Circumstances.-Many other factual patterns have been unsuccessfully urged upon the Court as constituting special circumstances wherein the failure to appoint counsel should be presumed prejudicial to the accused. Chief among them is the contention that the seriousness of the crime and possible punishment should be of substantial weight in determining whether conviction of a noncapital crime without counsel denied due process. In the Tozonsend case, the Court attempted to stem this argument by saying that its finding of prejudice was not in the least motivated by the fact that the petitioner had received a severe sentence of twenty years. ${ }^{29}$ This observation is emphasized by the finding in Carter $v$. Illinois ${ }^{30}$ and the Gryger case that the unrepresented indigents had not been deprived of their constitutional rights, although each had been sentenced to life imprisonment.

On behalf of the state attorney general, the principal contention has been that the accused has waived whatever constitutional rights he may have possessed. To the argument that a plea of guilty constituted waiver, the Court has answered that even if the petitioner was guilty of some offense, counsel was still necessary to ascertain that he was guilty as charged. ${ }^{31}$ In taking a strong stand against an emasculation of the right through an implication of waiver, the Court has likewise refused to find waiver in a failure to request appointment, and has consistently held that there must be an intelligent and competent refusal of counsel by an accused fully informed as to his rights. ${ }^{32}$ A lengthy delay in presenting the violation of his right to appointment might be thought to weigh against the petitioner because of the evidentiary problems presented by the petition, and on the new trial. However, an examination of the cases reveals that many of the successful petitions were raised many years after the illegal conviction. ${ }^{33}$

\section{State Statutes and the Right to Counsel}

At the time of the adoption of the Constitution, statutes in a few states directed that indigents facing a capital charge be assigned counsel. ${ }^{34}$ In the nineteenth century, scattered judicial opinions stated that the right

28. 312 U. S. 329 (1941).

29. See Townsend v. Burke, 334 U. S. 736, 741 (1948).

30. 329 U. S. 173 (1946).

31. Williams v. Kaiser, 323 U. S. 471,475 (1945).

32. Rice v. Olson, 324 U. S. 786 (1945). The value which indigents place upon representation is shown by the fact that in only one case coming before the Supreme Court has the record shown a deliberate and insistent rejection of counsel offered by the trial court. Adams v. United States ex rel. McCann, 317 U. S. 269 (1942).

33. E. g., Marino v. Ragen, 332 U. S. 561 (1947) (delay of twenty-two years; state confessed error); De Meerleer v. Michigan, 329 U. S. 663 (1947) (delay of fifteen years; petitioner released).

34. See note 2 supra and text. 
should be extended to noncapital cases. ${ }^{35}$ At the present time, all states place an affirmative duty upon the trial court to appoint counsel for those indigents facing a capital charge; but as has been indicated above, ${ }^{36}$ such action is a requirement of due process. In their treatment of the indigent's right to counsel in noncapital cases, the state statutes may be divided into four groups. The first group, a small minority of the fortyeight, provide that the trial judge shall advise the unrepresented defendant of his right to counsel, and upon a showing of indigency, appoint the same to aid him. ${ }^{37}$ The second group, comprising the majority of states, direct the trial court to appoint counsel for the defendant upon his request, and a showing of indigency. ${ }^{38}$ Such statutes can be justified only on the assumption that an accused is aware of his legal rights-an assumption which is unsupported by reality. It is significant that these same states impose an affirmative duty of appointment in capital cases. The third group leaves the appointment of counsel in noncapital cases to the discretion of the trial court. ${ }^{39}$ While a philosophical argument against such a statute is apparent-to wit, that if a right exists, the granting of it is not a matter of discretion-the objection can be rested upon more substantial grounds. In exercising his discretion, the trial judge will presumably examine the issues to determine whether they present sufficient complexity to require the aid of counsel. Yet, at arraignment, the indictment and plea form the sole basis for his decision. It seems evident that possible complexities of the case cannot be apparent at this time, and that if the trial judge decides that counsel is not required, valid defenses may never be revealed. In a small minority of the states, the statutory right to counsel is limited to capital cases. ${ }^{40}$ Finally, in some jurisdictions, narrow judicial interpretations have curtailed the statutory right to counsel. ${ }^{41}$ It is therefore clear that in only a few states is the right to counsel effectively granted those indigents who are ignorant of their rights-the very persons for whom statutory protection is necessary.

When the trial court has determined that representation is necessary, there are two sources from which counsel may be obtained. The traditional method calls for the appointment of a member of the local bar; such is the current practice in the federal courts and the majority of the states. A frequently voiced practical argument against an extension of the right to counsel is that an increased burden will be placed upon members of the bar if, as is possible, they are required to serve without fee, or in the alternative, that a heavy expense will be levied upon

35. See, e. g., Webb v. Baird, 6 Ind. 13, 18 (1854); Carpenter v. County of Dane, 9 Wis. 274,276 (1859).

36. See text at note 10 supra.

37. See, e. g., Cal. Penal Code $\$ 987$ (Deering, 1941) ; Conn. Gen. Stat. $\$ 8796$ (1949); N. Y. Code CrIM. Proc. \$308.

38. See, e. g., Ore. Comp. Laws Ann. \$26-804 (Supp. 1943) ; Wyo. Comp. Stat. ANN. $\$ 10-805$ (1945).

39. See, e. g., Md. AnN. Code, art. 26, \$7 (Flack, 1939); N. H. Rev. Laws, c. $428, \S 2(1942)$.

40. See, e. g., Miss. Code AnN. $\$ 2505$ (1942) ; Pa. Stat. Ann., tit. 19, §§ 783, 784 (Purdon, 1930).

41. Hamlin v. Commonwealth, $287 \mathrm{Ky} .22,152 \mathrm{~S}$. W. 2d 297 (1941) (judge-made requirement that defendant must request appointment); People v. Crandell, 270 Mich. $124,258 \mathrm{~N}$. W. 224 (1935) (statutory right to counsel not applicable when defendant has pleaded guilty). 
the state fisc where an individual statutory fee is provided. ${ }^{42}$ A number of states have established an office of public defender in an apparently successful attempt to answer these objections, and in addition, to make specialized counsel available to the indigent. ${ }^{43}$ Recent criticisms indicate that the system is not always so successful in practice as in theory, but the isolated examples of failure are outweighed by a general success. ${ }^{44}$ Faced with a current trend toward extension of the right to counsel, the system may be expected to find increasing favor with state legislatures.

\section{Procedural Paths for Raising the ObJection}

In order to comprehend the difficult obstacles which await an indigent seeking to assert a denial of his right to counsel, cognizance must be taken of his situation following conviction. His attempt to obtain belated legal representation may be frustrated by a not infrequent prison practice which places severe restrictions upon communication with the outside world during the initial period of confinement. ${ }^{45}$ The regular avenue of appeal is often closed to him by statutes which require that an appeal be perfected within a relatively short time after conviction, ${ }^{46}$ a difficult undertaking for one unrepresented at the trial. For these reasons, the contention will usually be presented by an extraordinary writ; in most jurisdictions the remedy would be habeas corpus; in a few, coram nobis or a writ of error would be proper. The remedy is at the discretion of the states, and their procedure must generally be followed. ${ }^{47}$ Unfortunately, a few jurisdictions provide no comprehensible procedure for raising this objection. ${ }^{48}$ Although all states permit the indigent to make his petition in forma pauperis, certain of them refuse to appoint counsel to plead the case. ${ }^{49}$ The frequent result is an insufficient petition and an inadequate oral argument. Finally, the court is often limited to the common law record, because of a statutory requirement that the trial transcript and bill of exceptions will be considered only when made avail-

42. See Holtzoff, supra note 5 , at 17 . In a compromise which satisfies neither objection, some states provide a totally inadequate fee. See, e. g., MISS. CoDE ANN. $\$ 2505$ (1942) (fifty-dollar maximum fee); VA. Cone ANN. \$3518 (Michie, 1942) (twenty-five-dollar maximum fee).

43. Among the states which have adopted some form of the public defender system are California, Connecticut, Illinois, Indiana and Nebraska.

44. For a favorable evaluation of the system, see Freeman, The Public Defender System, 27 MIcH. S. B. J. 13 (April, 1948). For an analysis of its defects, see Stewart, The Public Defender System Is Unsonnd in Principle, 32 J. AM. Jud. Soc'y 115 (1948). It is interesting to note that many foreign countries have adopted an equivalent form of representation. See Itr., 20 A. B. A. J. 252 (1934).

45. See Johnson v. Zerbst, 304 U. S. 458, 462 (1938); United States ex rel. Bongiorno v. Ragen, 54 F. Supp. 973, 975 (N. D. Ill. 1944) (prison officials prohibited the sending of petitions to the courts).

46. E. g., LA. Code Crim. LAw \& Proc., art. 542 (Dart, 1943) (ten days after sentence to make motion of appeal); N. Y. CoDe CrIM. Proc. $\$ 521$ (thirty days within which to file appeal).

47. Carter v. Illinois, 329 U. S. 173, 175 (1946). But the exhaustion principle is not applicable when state remedies are illusory. See Marino v. Ragen, 332 U. S. 561,564 (1947) (concurring opinion).

48. Id. at 567. Mr. Justice Rutledge castigated Illinois for what he termed a procedural morass offering no substantial relief to the petitioner.

49. People ex rel. Ross v. Ragen, 391 I1l. 419, 63 N. E. 2d 874 (1945) (habeas corpus a civil proceeding, hence appointment of counsel not a constitutional right). But cf. Walker v. Johnston, $312 \mathrm{U}$. S. 275, 278 (1941): "We . . . appointed counsei for the petitioner to insure adequate presentation at our bar." 
able at the petitioner's expense. ${ }^{50}$ In such a case, the United States Supreme Court will limit the scope of its review to the record before the state court. ${ }^{51}$ These procedural problems furnish a number of nonfederal grounds upon which to rest a denial of the petition, and since by definition, state remedies have not been exhausted, the federal courts are without jurisdiction..$^{\mathbf{2}}$ As a result, a series of petitions must be directed to the state courts before a decision on the merits is obtained. ${ }^{53}$

Assuming a decision by the state court that failure to appoint counsel did not violate a federal right, and an exhaustion of remedies in the state appellate courts, the indigent can petition the Supreme Court for a writ of certiorari, with an excellent chance of its being granted. ${ }^{54}$ Another avenue through which the petitioner may eventually reach the Supreme Court is a petition to a federal district court for a writ of habeas corpus. Until recently, an exhaustion of state remedies, and a petition for certiorari from the judgment of the state supreme court, were prerequisites. $^{55}$ In Wade $v$. Mayo, ${ }^{58}$ the Court modified this rule by saying that even though there had been no petition for certiorari, the district judge could at his discretion entertain the habeas corpus petition if injustice might otherwise result. In the event that the petition contains allegations which, if substantiated, would constitute a denial of the constitutional right to counsel, the district court must grant a hearing, ${ }^{57}$ and should it refuse to discharge the petitioner, he may press his claim to the appellate levels of the federal system.

\section{The Results of a Successful Habeas Corpus Petition}

An extension of the right to court-appointed counsel by the Supreme Court is frequently opposed on the ground that the retroactive effect of such a ruling would be to release from penal servitude many presently incarcerated criminals. ${ }^{58}$ An examination of the subsequent history of

50. E. g., Ill. ANn. Stat., c. 53, $\$ 81$ (Smith-Hurd, Supp. 1948). At some state trials, no stenographer is present unless requested and remunerated by the defendant. The procedure in federal district court offers a welcome contrast in that a courtappointed reporter is present at every trial. 58 STAT. 5 (1944), as amended, 28 U. S. C. $\$ 753$ (Cong. Serv. 1948).

51. Carter v. IIlinois, 329 U. S. 173 (1946).

52. Hedgebeth v. North Carolina, 334 U. S. 806 (1948) ; accord, Phyle v. Duffy, 334 U. S. 431 (1948).

53. See Note, 15 U. of Chr. L. REv. 107, 120 (1947) (seven to twelve petitions often necessary before Illinois procedural requirements satisfied). Compare the attitude of the Supreme Court that a habeas corpus petition is to receive a liberal construction. Holiday v. Johnston, 313 U. S. 342, 350 (1941).

54. See Carter v. Illinois, 329 U. S. 173, 174 (1946): "In view of the importance of the claim if valid, we brought the case here." One cannot but suspect that the alacrity with which the Supreme Court grants these petitions is motivated by an awareness of inadequate state remedies.

55. Ex parte Hawk, 321 U. S. 114 (1944).

56. 334 U. S. 672,681 (1948).

57. Rev. STAt. \$755 (1875), as amended, 28 U. S. C. $\$ 2253$ (Cong. Serv. 1948), Walker v. Johnston, 312 U. S. 275 (1941). But it has been held that when the Supreme Court has denied certiorari after a state decision on the merits of the federal claim, the district court will not ordinarily entertain the petition. United States ex rel. Mills v. Ragen, 77 F. Supp. 15 (N. D. Ill. 1948).

58. See Foster v. Illinois, 332 U. S. 134,139 (1947). It has been suggested that by making failure to furnish counsel reversible error on appeal, but providing that in a collateral attack, prejudice must be shown, a higher standard will be created for the future while the stringent rule in collateral attack will prevent a general jail delivery. Frank, The United States Supreme Court, 15 U. of CHI. L. REv. 1, 27 n. 117 (1947). This solution apparently proceeds on the questionable assumption that an unrepresented indigent will be able to perfect his appeal within the relatively short time permitted him. See note 46 supra. 
cases where the petitioner has been released because of a failure to appoint counsel for him fails to support this contention. In these cases, the basis for releasing the relator from confinement is that by its failure to appoint counsel, the trial court lost its jurisdiction over the defendant, and hence could not enter a valid judgment. Since the original trial is of no legal effect, a "second" trial does not constitute double jeopardy. ${ }^{59}$ There have been instances in which the accused received a heavier sentence in the second trial.60 The Supreme Court decisions finding a violation of due process in the failure to appoint counsel for an indigent have been predicated upon the concept that at a particular point in the trial, lack of counsel was prejudicial. Under such rulings, the court assuming jurisdiction in the second trial must decide how much of the original proceedings have been vitiated by the error. In theory, three solutions are possible: (1) to render the original proceedings void $a b$ initio, thus requiring the state to proceed against the accused by a new indictment or information; (2) to suffer the original indictment to stand, but to permit the accused to submit a new plea; $(3)$ to strike only that part of the trial subsequent to the point of prejudice. The striking of the indictment appears objectionable both because the statute of limitations may have run against the offense, and because it can hardly be said that the validity of the indictment was affected by the error; whatever the rationale, no court has required this solution. ${ }^{61}$ The second possibility has found most favor with courts facing the problem, ${ }^{62}$ and appears to supply the most equitable balance between the needs of accused and state. The point-of-prejudice theory is unlikely to receive judicial approbation because, notwithstanding selection by the Supreme Court of a particular portion of the trial wherein lack of counsel was prejudicial, it is highly speculative to assume that prior portions were not also adversely affected by the error. ${ }^{63}$ A more frequently litigated question is whether, assuming conviction on the second trial, the defendant must be given credit for time served under the void sentence. ${ }^{64}$ In the absence of a statute, ${ }^{65}$ the prevailing view holds that while the trial judge may shorten the maximum length of the new sentence, he has no power to resentence the defendant nunc pro tunc

59. Stroud v. United States, 251 U. S. 15 (1919) ; Murphy v. Massachusetts, 177 U. S. 155 (1900).

60. Robinson v. United States, 324 U. S. 282 (1945). On release from his original life sentence because of a failure to appoint counsel the defendant was retried, and sentenced to death. The Supreme Court affirmed the conviction.

61. In State v. Stroemple, 355 Mo. 1147, 199 S. W. 2d 913 (1947), the state elected to proceed against the defendant by way of a new indictment, and this procedure was upheld. It has been unsuccessfully urged by the accused that although the statute of limitations has not run against his offense, a retrial consequent upon a lengthy delay is invalid as a violation of the constitutional right to a "speedy trial." Commonwealth v. Mitchell, $153 \mathrm{~Pa}$. Super. 582, 34 A. 2d 905 (1943), aff'd mem., $349 \mathrm{~Pa} .559,37$ A. 2d 443 (1944); cf. In re Knight, 144 Ohio St. 257, 264, 58 N. E. 2d 671, 674 (1944).

62. Commonwealth ex rel. Townsend v. Burke, 63 A. $2 d 77$ (Pa. 1949); Ex parte Traxler, 148 Tex. Crim. 550, 189 S. W. 2d 749 (1945).

63. State v. Stroemple, 355 Mo. 1147, 199 S. W. 2d 913 (1947). The petitioner unsuccessfully contended that the trial court erred in striking his plea to the original indictment.

64. In many cases, the relator has served a considerable portion of his sentence before being released under habeas corpus. See note 33 supra.

65. E. g., Mich. Stat. ANN. $\$ 28.1085$ (Callaghan, Supp. 1947) ; N. Y. Penal LAW § 1943; PA. Stat. ANN., tit. 19, §894 (Purdon, Supp. 1948). 
the date of the original sentence. ${ }^{68}$ This harsh rule has been applied even where time served under the void sentence exceeded the maximum penalty possible under the second conviction. ${ }^{67}$ Such decisions indicate that release under habeas corpus is far from the boon popularly supposed, and that the voiding of convictions for failure to furnish counsel has not had the result of enabling criminals to escape just punishment, but rather of insuring that their punishment be just.

\section{Evaluation}

The tenor of recent decisions indicates that, for the present, the Supreme Court will adhere to the technique of examining each case coming before it for special circumstances in which the lack of counsel was prejudicial, and hence a denial of due process. This view represents a compromise between a reluctance to meddle in the local administration of justice, ${ }^{68}$ and a desire to insure the "fundamental principles of liberty and justice" required by the due process clause. ${ }^{69}$ As has been pointed out in the foregoing discussion, this subjective approach has led to conflicting decisions, and the aggregate of cases decided since 1942 can scarcely be said to furnish the states with a reliable guide as to when due process requires the appointment of counsel in noncapital cases. Complaint has been made of the burden placed upon state and federal courts by the large number of appeals and petitions alleging denial of counsel, ${ }^{70}$ and it has been argued that a broadened rule will mean an increased burden. In the case of state courts, the present burden is the result of an intransigent attitude which places every possible procedural obstacle in the way of one asserting this right. ${ }^{71}$ The federal burden is the result of the narrow scope of the right under state law, and of the uncertainty as to the federal due process requirement which makes the filing of a petition in federal court a good gamble. In fact, the existing appellate burden would be lightened by a broader rule eliminating the current substantive and procedural uncertainty. The adoption of a rule which requires state courts to appoint counsel for indigents in all criminal cases above the level of petty offenses seems justified on both constitutional and policy grounds. The argument that criminal procedure is a matter for state control under the police power begs the question inasmuch as the requirements of the Constitution stand paramount over state rights. Moreover, recent Supreme Court decisions on other aspects of criminal procedure show the rule to be more honored in the breach than in the observance. ${ }^{72}$ One justification for refusing to impose an absolute

66. People v. Judd, 396 Ill. 211, 71 N. E. 2 d 29 (1947) ; State ex rel. Drankovich v. Murphy, 248 Wis. 433,22 N. W. 2 d 540 (1946). Contra: Owen v. Commonwealth, $214 \mathrm{Ky} .394,283$ S. W. 400 (1926) ; Stonebreaker v. Smyth, 187 Va. 250, 46 S. E. 2d 406 (1948). Since few convicts serve out their full terms, a reduction in the maximum length of the sentence is of slight value to them.

67. In re Doelle, $35 \mathrm{~N}$. W. 2d 251 (Mich. 1948). Contra: In re Leypoldt, 32 Cal. App. 2d 518, 90 P. 2d 91 (3d Dist. 1939).

68. See Foster v. Illinois, 332 U. S. 134, 139 (1947).

69. Hebert v. Louisiana, 272 U. S. 312, 316 (1926). (1948).

70. Goodman, Use and Abuse of the Writ of Habeas Corpus, 7 F. R. D. 313, 315

71. See Note, 15 U. of CHr. L. Rev. 107, 119 (1947).

72. For typical examples of federal control over state criminal procedure, see In re Oliver, 333 U. S. 257 (1948) (requirement of a public trial) ; Patton v. Mississippi, 332 U. S. 463 (1947) (proscription of state practice excluding Negroes from juries). 
requirement upon the states in the matter of appointing counsel is that they should be allowed to meet federal behests in their own fashion; ${ }^{73}$ yet, the actual control over state criminal procedure is just as great, though less effective, under the present piecemeal determination of prejudicial error as it would be under a definitive rule.

To say that in a capital case prejudice is immaterial, that in a few noncapital situations prejudice will be presumed, and that in the remaining cases prejudice must be established, is to draw distinctions which are unjustified in theory and unwieldy in practice. A constitutional distinction to the effect that an unrepresented defendant charged with a capital crime, but sentenced to life imprisonment has been denied due process, while one receiving a life sentence under a noncapital charge has not, seems unjustifiable even under narrow legalistic reasoning; yet an aggregate of two Supreme Court decisions has reached this result. ${ }^{74}$ All would agree that an indigent's right to be represented by court-appointed counsel is grounded upon his need for one skilled in the paths and pitfalls of the law. This need is based not upon a capital-noncapital dichotomy, but instead upon the inability of any layman adequately to defend himself. ${ }^{75}$ The effect of the present requirement that in the bulk of the cases prejudice must be shown, is to proclaim the balance weight between liberty and imprisonment to be the tenuous chance that the prejudice suffered was made of record. From a practical viewpoint, the retroactive effect of a broadened rule would not be great, ${ }^{76}$ and retroactivity did not seem to weigh heavily with the Court where capital crimes were concerned. Moreover, there appears to have been no exodus of federal prisoners in the decade since the adoption of the all-inclusive rule in Johnson v. Zerbst. While it is true that state legislation would avoid the problem of retroactivity, the legislatures have shown no alacrity to amend their presently unsatisfactory statutes on the right to counsel, and give little indication of a future intention to do so. ${ }^{77}$

The recent cases indicate that the Supreme Court is gradually increasing the number of special circumstances in which state courts must furnish the indigent with counsel. The evolution of the present rule in the federal courts supports the belief that within the foreseeable future, the current minority position will become the rule of decision, and will require that counsel be appointed for indigents in all trials above the petty offense level.78 Such a rule may be grounded either upon the rationale that the "fair trial" required by the due process clause has not been granted where an unrepresented indigent was convicted, or, less likely, upon acceptance of the contention that the Fourteenth Amendment made the guarantees of the Bill of Rights binding upon the states. Under the system of case-by-case determination, it is conceivable that an exact definition of a petty offense will not be delineated; nor indeed

73. See Uveges v. Pennsylvania, 335 U. S. 437, 449 (1948) (dissenting opinion).

74. Compare Tomkins v. Missouri, 323 U. S. 485 (1945), with Gryger v. Burke, 334 U. S. 728 (1948).

75. See Bute v. Illinois, 333 U. S. 640, 682 (1948) (dissenting opinion).

76. See text at note 58 supra.

77. Illinois offers the outstanding exception to this statement. See IIl. R. Prac. \& Proc., 27A, 400 I11. 22 (1948).

78. A distinction between the procedural requirements for petty offenses and for serious crimes would not be novel to the Court. See Schick v. United States, 195 U. S. 65,68 (1904) (petty offenses do not require trial by jury). 
is one essential. ${ }^{79}$ If an exact definition is felt advantageous, conceivably Congress could furnish it under the authority of the implementation provision of the Fourteenth Amendment. For example, the statute could provide that counsel be furnished in all criminal actions where the possible period of incarceration would exceed six months, thus embracing the vast majority of crimes which require the assistance of counsel. Regardless of supplemental legislation, the recommended rule is detrimental to no one, and would be of immeasurable aid to unfortunate indigents facing penal servitude. At best the objections are technical, and technicalities should not stand as a bar to a rule which insures justice to all, not merely to those who can afford its price.

$$
\text { A. C. D., Jr. }
$$

\section{Applicability of Federal Statutes to Noncontiguous Areas}

The problem of the applicability of federal statutes to noncontiguous areas has received little consideration from either legislators or courts. Most statutes merely designate the area encompassed, by the use of such phrases as "territories and possessions of the United States." Others negatively exclude "foreign countries" from their coverage. ${ }^{1}$ Legislative history sheds little light on the precise localities intended to be covered and serves as evidence of the lack of congressional attention to this phase of statutory draftsmanship. ${ }^{2}$ The reason lies in the fact that, historically, few controversies resulted from this cursory treatment, for the few extraterritorial areas under the exclusive sovereignty of the United States, such as Hawaii and Puerto Rico, had sufficient identity of characteristics to warrant this lumping together. The many new relationships established between this country and extraterritorial areas as a consequence of the recent war, however, make it imperative that Congress and the courts address themselves specifically to the differences that exist. To aid in this determination an analysis will be made of the various classifications of noncontiguous areas. A discussion of past and present considerations should_serve as a guide to the intelligent solution of the problems of statutory coverage. The areas treated will be classified as: (1) owned areas under exclusive United States sovereignty; $(2)$ the Panama Canal Zone-an anomaly; (3) areas leased by the owner-State to the United States; (4) trusteeship territories; and (5) areas occupied by military forces.

\section{OWned Areas Under Exclustve Sovereignty}

Areas actually ceded to the United States ${ }^{3}$ present no international problem because there can be no conflict of national rights. Thus, only

79. Cf. Mr. Justice Holmes in Irwin v. Gavit, 268 U. S. 161, 168 (1925) : "Neither are we troubled by the question where to draw the line. That is the question in pretty much everything worth arguing in the law. . . Day and night, youth and age are only types."

1. For a compilation of sixty-three statutes using the territories-and-possessions formula, see Vermilya-Brown Co. v. Connell, 335 U. S. 377, 398 n. 11 (1948) (dissenting opinion).

2. Brief for United States as Amicus Curiae, p. 13, Vermilya-Brown Co. v. Connell, supra note 1 .

3. E. g., Alaska, American Samoa, Guam, Puerto Rico, and the Virgin Islands. 
national interests are to be considered in dealing with these annexed territories; there is no problem of the interpretation of agreements among several nations. This still leaves for determination, however, the status of such territories in relation to continental United States.

No difficulties of consequence were encountered until the beginning of the twentieth century, when the United States had acquired several island areas (Hawaii, Puerto Rico) distant from the American continent. Shortly thereafter the Supreme Court, in De Lima v. Bidwell, ${ }^{4}$ decided that these areas were no longer "foreign countries" with reference to the application of tariff regulations. In a companion case, Downes v. Bidwell, ${ }^{5}$ however, it was held that though these areas belonged to the United States they were not "incorporated" into the United States. This meant that the geographical coverage of the Constitution did not include these areas. From the five-to-four decision in this latter case stems the now established doctrine of "territorial incorporation." 6 In incorporated territories the Constitution applies to its full extent. In unincorporated territories, though "fundamental rights" are guaranteed, "procedural rights" are not." The differences are not clear and can only be determined by reference to court decisions. ${ }^{8}$ It appears that the basic reason for this distinction was the desire to permit the legislative and executive branches to have a free hand in dealing with these areas, unhampered by constitutional restriction. This was deemed necessary because of the great differences in cultural and legal institutions, and the desire to avoid a disruption of native mores and institutions-a recognition by the judiciary of the need for specific congressional treatment of noncontiguous areas.

Although these early cases make the distinction between incorporated and unincorporated territories, they do not define the terms or give tests by which they can be determined. However, in Balzac v. Puerto Rico, decided in 1922, the Supreme Court made it absolutely clear that incorporation is not to be assumed without an express declaration of Congress or an implication so strong as to exclude any other view. The Court assumed that when Congress intended to incorporate an area, it would do so deliberately and with a clear declaration of purpose, and not leave it to implication or construction. ${ }^{9}$ The organic act which, among other things, conferred United States citizenship on Puerto Ricans was held not to contain sufficient evidence of congressional intent to incorporate. Thus, even in relation to areas owned by the United States, there is a reluctance on the part of the judiciary to classify an area as incorporated in the absence of the clearest intent of the political branches.

In addition to the classification of owned areas into incorporated and unincorporated territories, ${ }^{10}$ there exists the further classification based

4. 182 U. S. 1 (1901).

5. 182 U. S. 244 (1901).

6. See Coudert, The Evolution of the Doctrine of Territorial Incorporation, 26 Cot. L. Rev. 823 (1926).

7. See id. at 850 .

8. Dorr v. United States, 195 U. S. 138 (1904) (no constitutional duty to provide Philippine citizens with trial by jury); Hawaii v. Mankichi, 190 U. S. 197 (1903) (despite annexation by joint congressional resolution, Hawaii not incorporated, and no constitutional right to grand jury indictment).

9. Balzac v. Puerto Rico, 258 U. S. 298, 311 (1922).

10. Alaska and Hawaii are the only two areas with the status of incorporated ter-

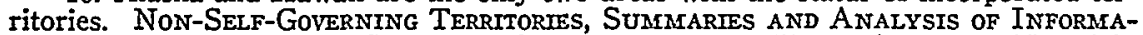
tion Transaitted to the Secretary General during 1947 at 395, 420 (U. N. 1948). And see Rasmussen v. United States, 197 U. S. 516, 525 (1905) (series of congressional acts held inferentially to indicate intent of Congress to incorporate Alaska). 
upon the enactment by Congress of an organic act to serve as a "constitution" for the area. These areas are classified as "organized but unincorporated territories." Other areas not governed by an organic act are classed as "unorganized possessions." 11 They are usually under the jurisdiction of the Secretary of the Navy. All owned areas, by court decision, have been held to come within the purview of statutes applying to "territories and possessions." 12 The fact that the statute is enacted prior to an area's annexation does not prevent its being covered. ${ }^{13}$

The common element in all localities thus far discussed has been "ownership," with sovereignty in the United States. It has been strongly contended that a transfer of sovereignty is essential if an area is to be classed as a possession. ${ }^{14}$ If this view be accepted, the status of such areas-as possessions-must of necessity be determined by the political, $i$. e., the legislative and executive, branches. ${ }^{15}$ It is interesting to note that in Vermilya-Brown Co. v. Connell, decided in 1948, the Supreme Court by-passed this argument by stating that the determination of sovereignty by the political departments "does not debar courts from examining the status resulting from prior action" 18 - does not debar the courts even though such action did not invest the United States with sovereignty. The authorities cited for this proposition are two cases involving territories over which the United States' sovereignty had been established by the Department of State, ${ }^{17}$ and the cases therefore do not support the proposition espoused by the Court. If sovereignty is necessary in order to classify an area as a possession, it was improper for the Court in this case to hold that the Fair Labor Standards Act (effective in "territories and possessions") applies to an area over which the Court agrees that the United States does not have sovereignty.

Granting that ownership is sufficient to place an area within the classification of a possession, what is the nature of other areas not owned exclusively by the United States? Experience with the Panama Canal Zone highlights the increased difficulties and confusion that result from acquiring an area under an agreement which does not provide for actual annexation.

\section{The Canal Zone-An Anomaly}

The Isthmian Canal Convention 18 is comprehensive in that it gives to the United States, in perpetuity, the greatest possible jurisdiction in the Panama Canal Zone, without actually ceding the area to this country. It provides, inter alia, that the United States shall have "all the rights, power and authority within the zone . . . which the United States would possess and exercise if it were the sovereign . . . to the entire ex-

11. Puerto Rico and the Virgin Islands are classed as organized but unincorporated territories; American Samoa and Guam, as unorganized United States possessions. Non-Self-Governing Territories, Sumararies and ANalysis of Information Transmitted to the Secretary General during 1947 at 405, 412, 429, 442 (U. N. 1948).

12. In re Lane, 135 U. S. 443 (1890). But cf. Ex parte Morgan, 20 Fed. 298 (W. D. Ark. 1883).

13. Puerto Rico v. Shell Co., 302 U. S. 253 (1937).

14. Brief for United States as Amicus Curiae, p. 18, Vermilya-Brown Co. v. Connell, 335 U. S. 377 (1948).

15. Jones v. United States, 137 U. S. 202 (1890).

16. Vermilya-Brown Co. v. Connell, 335 U. S. 377, 380 (1948).

17. Hooven \& Allison Co. v. Evatt, 324 U. S. 652 (1945); De Lima v. Bidwell, 182 U. S. 1 (1901).

18. 33 Stat. 2234 (1903). 
clusion of the exercise of the Republic of Panama of any such sovereign rights, power or authority." 19 It would seem that this agreement is sufficiently comprehensive to avoid any international difficulties. Yet, in 1946, when the United States included the Zone in its report to the United Nations on nonselfgoverning territories, ${ }^{20}$ the Panamanian delegation strongly objected in the General Assembly, contending that sovereignty over the Canal Zone remained in the Republic of Panama.21 In its 1947 report to the United Nations, therefore, the United States omitted this area "pending clarification of this quesion with the Republic of Panama." 22

If it is possible for one nation to retain "sovereignty" and yet grant in perpetuity the exercise of "sovereignty," then this is the existing situation. That the controversy involves more than a mere logomachy is evidenced by the Panama Supreme Court's holding that its jurisdiction might be extended to cases arising within the Zone and involving the Zone's residents. ${ }^{23}$ That court has also decided that the area is not "foreign territory" in relation to the Republic. ${ }^{24}$

In the determination of the Zone's status by our own Government, there exists confusion. The executive department maintains the position that the United States exercises full sovereign rights, and in a most recent statement is careful to exclude this area from those over which we are sovereign. ${ }^{25}$ On the other hand, shortly after the Convention was concluded, the United States Supreme Court commented that "it is hypercritical to contend that the title of the United States is imperfect, and that the territory described does not belong to this Nation, because of the omission of some of the technical terms used in ordinary conveyances of real estate." 26 In a later case, however, the Court held the Zone to be a foreign port within the meaning of a statute dealing with compensation allowable for transportation of mail by American ships between the United States and "any foreign port." 27 These apparent inconsistencies stem from an attempt to arrive at a practical result with respect to the particular controversy before the Court.

The legislative branch has reflected this confusion of status in many statutes by failing to maintain a consistent classification of this area. ${ }^{28}$

19. 33 STAT. 2234, art. III (1903).

20. See Non-Self-Governing Territories, Sumimaries of Information TransMitTed to the Secretary General dURING 1946 at 121 (U. N. 1947). 1947).

21. The United States and Non-Self-Governing Territories $21 \mathrm{n} .1$ (U. $N$

22. Summary of Information Transmitted by the Government of the United States of America (U. N. Release A/320, July 25, 1947).

23. 2 HaCkWORTH, Digest OF INTERnational LAW 172 (1941).

24. In re Bartlett, Lauterpacht, Annual Digest 1929-1930, case no. 51 (Panama Sup. Ct. 1930).

25. Letter to the Attorney General from the Acting Legal Adviser to the Secretary of State, quoted in Memorandum for United States in Support of Petition for Rehearing [hereinafter United States Memorandum], p. 8, Vermilya-Brown Co. v. Connell, 335 U. S. 377 (1948).

26. Wilson v. Shaw, 204 U. S. 24, 33 (1907).

27. Luckenbach S. S. Co. v. United States, 280 U. S. 173 (1930)

28. E. g., Atomic Energy Act of 1946, 60 STAт. 774, 42 U. S. C. \$1818(d) (1946) ("The term 'United States," when used in a geographical sense, includes all Territories and possessions of the United States and the Canal Zone"); Settlement of Mexican Claims Act of 1942, 56 STAT. 1063, 22 U. S. C. \$672 (1946) ["The term 'United States,' when used in a geographical sense, includes . . . possessions (including the Philippine Islands), and the Canal Zone"]; Civil Aeronautics Act of 1938, 52 STAT. 979, as amended, 49 U. S. C. \$401(29) (1946) ["'Possessions of the United States' means ... (b) the Canal Zone"]. 
Congressional awareness of this problem has led to specific inclusion or exclusion of the Canal Zone, by name, from a statute's coverage. ${ }^{29}$ Where no statutory mention is made, and in the absence of controlling court decisions, administrative agencies usually treat the area as a possession under United States sovereignty, or seek clarification from the Department of State or other governmental agencies. ${ }^{30}$

The strategic and commercial implications inherent in any conflicts and inconsistencies that arise, appear to be the prime factors affecting their disposition, the agreement with the Republic of Panama being comprehensive enough to give this country a free hand in their solution.

\section{LeAsed Areas}

In 1941 the United States leased several areas from Great Britain for a period of ninety-nine years. ${ }^{31}$ As contrasted with the sweeping authority conferred on the United States by the Isthmian Convention, ${ }^{32}$ this agreement confers only limited rights. The lease confines our usage to the establishment and maintenance of military and air bases and provides, inter alia, that no business enterprises may be established, ${ }^{33}$ that immigration laws are suspended only to admit American military forces and other persons connected with the bases, and that customs duties are lifted for limited purposes. ${ }^{34}$ Many of the problems implicit in treaty interpretation may possibly arise in relation to these areas. International interests and rights, as well as national policy, will have to be considered in dealing with the leased bases.

Before any federal statutes can be said to apply, it must first be determined whether this country has jurisdiction under the terms of the agreement. Granting such jurisdiction, there is the further problem of whether statutes using the customary "territories and possessions" clause apply to leased bases. Do these areas fit into any of the categories discussed above, so that a statute applying to possessions will also apply to the leased areas, or are they definitely not possessions and therefore to be excluded from such a statute's coverage? Does the issue resolve intto one of statutory interpretation, or one of interpretation of the lease agreement? These questions already have passed from the realm of philosophical speculation into the arena of practical controversy via the recent decision in Vermilya-Brozen Co. v. Connell. ${ }^{35}$ The Supreme Court, four justices dissenting, ${ }^{36}$ held that the Fair Labor Standards Act, ${ }^{37}$ which by its terms covered "territories and possessions of the United States," was operative at a leased base in Bermuda. The district court

29. E. g., Communications Act of 1934, 48 STAT. 1065, as amended, 47 U. S. C. $\$ 153(\mathrm{e})$ (1946) ["possession of the United States (other than the Canal Zone)"]; Air Commerce Act of 1926, 44 STAT. 573, as amended, 49 U. S. C. $\$ 170$ (b) (1946) (applies to possessions, "but shall not include the Canal Zone").

30. Letter to the Solicitor General from the Administrator of the Wage and Hour and Public Contracts Divisions of the Department of Labor, quoted in United States Memorandum, p. 20.

31. 55 Stat. 1560 (1941).

32. See text at notes 18-19 supra.

33. 55 Stat. 1560, art. XIV(1) (c) (1941).

34. 55 Stat. 1560, art. XIII(1) (1941).

35. 335 U. S. 377 (1948). Justices Black, Reed, Douglas, Murphy, and Rutledge were in the majority.

36. The Chief Justice and Justices Frankfufter, Jackson, and Burton.

37. 52 Stat. 1060 (1938), as amended, 29 U. S. C. $\$ 201$ et seq. (1946). 
had held the Act inapplicable on the ground that sovereignty was a necessary requisite for the area to be a possession, and whether the United States had sovereignty was a political question. ${ }^{38}$ The Department of State had decided that the necessary sovereignty was lacking; ${ }^{39}$ ergo, the Act did not apply. The district court's conclusion was perfectly logical if possession is limited to a historical definition, for prior to the acquisition of leased bases the only areas that could have been included were those over which the United States exercised sovereignty. However, the Court of Appeals for the Second Circuit reversed the decision, ${ }^{40}$ and rejected the view that this was a political question. After examining the lease agreement the court decided that the effect of its various provisions "compels the conclusion that the areas are subject to fully as complete control by the United States as obtains in other areas long known as 'possessions' of the United States." 41 This conclusion was most unfortunate and seems erroneous, for a cursory reading of the lease agreement ${ }^{42}$ is sufficient to disclose that American rights in these areas do not remotely approach the complete sovereignty exercised in owned areas and the Panama Canal Zone.43 This lumping together of the several categories of areas discussed in this Note is the precise thing that the courts must avoid, for it is beyond the judicial province to annex territory by decision. The history of the negotiations discloses that annexation was contemplated but was rejected because of this Government's reluctance to incur any unnecessary obligations. ${ }^{44}$ The court of appeals decision has invoked hostile criticism from England ${ }^{45}$ and from the Department of State. ${ }^{48}$

The Supreme Court, though affirming the decision, did so on entirely different grounds. The majority reasoned that since there was jurisdiction sufficient to warrant regulation of wages and hours at the base, the sole issue was one of statutory interpretation. The word possession in the Act being ambiguous and not capable of a definition that would include or exclude the base, the Court stated that it must examine the policy of the Act, and the Court found it reasonable to interpret its provisions as having force where the nation had "sole power" 47 rather than to limit its coverage to sovereignty. Such an interpretation was consonant with the Administrator's inclusion of the Canal Zone within the meaning of possession. The Court concluded, therefore, that the policy warranted an interpretation of the word possession to include "foreign territory" under lease for bases. ${ }^{48}$

38. Connell v. Vermilya-Brown Co., 73 F. Supp. 860 (S. D. N. Y. 1946).

39. Id. at 861 .

40. Connell v. Vermilya-Brown Co., 164 F. $2 d 924$ (2d Cir. 1947).

41. Id. at 927 .

42. See text at notes 33-34 supra.

43. See text at notes 18-19 supra.

44. 1 Hull, Memoirs 834 (1948).

45. ". . . it is submitted that the court went too far . . . since (i) the control is not in fact so complete in view of the various limitations on United States authority to which the court did not refer. . . " Note, 2 INT'L L. Q. 235, 237 (1948).

46. ". . . the Department of State feels constrained to inform us that it 'regards as unfortunate' the conclusion of the court below. . . " Vermilya-Brown Co. v. Connell, 335 U. S. 377, 401 (1948) (dissenting opinion).

47. $I d$. at 390 (emphasis added).

48. Ibid. 
While the Supreme Court must confine itself to the narrow issue presented by a particular case, this decision leaves much to be desired. First, the Court avoided the political question by agreeing with the Department of State's determination that the United States did not have sovereignty and that the base was foreign territory. However, it seems the Court was wrong in stating that this country has "sole power" in the area. ${ }^{49}$ Unfortunate consequences have already resulted from the Court's failure openly to repudiate the reasoning of the court of appeals. The Administrator's inclusion of the Panama Canal Zone within the meaning of possession ${ }^{50}$ was not a valid factor for the Court to consider in reaching its conclusion. ${ }^{51}$ The Court in its anxiety to give a liberal construction to this remedial statute overlooks the practical difficulties resulting from its decision. ${ }^{2}$ These difficulties have been pointed out by the Departments of State ${ }^{\mathbf{5 3}}$ and Labor, ${ }^{54}$ and by the Army ${ }^{55}$ and Navy. ${ }^{56}$ Further, in merely holding that this Act applies to the bases, the Court opens the door to the possible application of this and all similarly worded

49. See text at notes $33-34,45-46$ supra.

50. See text at note 48 supra.

51. Compare the exclusive exercise of sovereignty in the Canal Zone with the limited rights in leased areas.

52. Actually, few American workmen are affected since most receive hourly rates and overtime benefits exceeding statutory requirements. Letter to the Attorney General from the Secretary of the Army, quoted in United States Memorandum, p. 11.

53. "The Department does not share the assurance of the Court that the house of assembly of Bermuda or other colonial legislatures might not undertake legislation similar to the Fair Labor Standards Act to control labor relations on the bases. . . . administrative difficulties have arisen in the bases by reason of the application to contractors' employees of workmen's compensation laws of both the United States and the colonies concerned." Letter to the Attorney General from the Acting Legal Adviser to the Secretary of State, quoted id. at 8.

54. The Administrator of the Wage and Hour and Public Contracts Divisions of the Department of Labor anticipates two major problems as a result of the Court's decision. First, there is the problem of determining whether other defense bases are covered by the Act. This the Administrator must do, pending authoritative guidance from the courts. Since under this decision, he can no longer rely upon traditional concepts of sovereignty, or State Department determinations, he must enter a field of interpretation unaided by his previous experience with the Act, legislative history, the language of the Act, or court decision. The determination may involve interpretation of international agreements with which, again, he has no experience. Thus he does not know whether defense bases such as Arabia, Canada, Greece, Iceland and Okinawa are covered. Second, he anticipates difficulties in applying the Act in areas over which the United States does not exercise full sovereignty, especially where foreign employers and alien labor are involved. Problems of courts with proper jurisdiction and venue to apply the Act's sanctions are bound to arise, and the Wage and Hour Division has neither the appropriation nor the organization to enforce the Act in far-flung outposts. Letter to the Solicitor General, quoted id. at 20.

55. It is anticipated that, in connection with public contracts, the Government will suffer increased costs running into the hundreds of millions. The most serious of the problems resulting from the decision is that native workmen (who outnumber American workmen by ten to one) are now covered by the Act. In the hiring of natives, "the local government in many countries will impose maximum wage standards which dare not be violated." These governments contend that to pay natives according to American standards would seriously disrupt the local economy. The Court's ruling that natives are covered and that these areas are possessions may cause foreign governments to compel curtailment or abandonment of projects, and will hinder future arrangements for construction on foreign soil. Letter to the Attorney General from the Secretary of the Army, quoted id. at 11.

56. It is the Navy Department's policy to employ local labor at leased bases to the maximum extent, and to make wage and labor practices conform as nearly as possible to the usual standards of the particular locality. Application of the Fair Labor Standards Act "may well create conditions which would adversely affect the cooperation heretofore given Navy contractors by local authorities." Letter to the Attorney General from the Acting Secretary of the Navy, quoted id. at 18. 
statutes to many other types of areas, e. g., trust territories and occupied areas. Whether other acts also apply to leased bases is not decided by this case; query whether each act must come before the courts for a determination based on the "statute's policy." In the interim there can be no certainty as to which of these acts does have extraterritorial effect.

Spelar $v$. United States ${ }^{57}$ is an example of the adverse consequences resulting from the Supreme Court's decision. The District Court for the Eastern District of New York held that the Federal Tort Claims Act 58 (excluding from its coverage any claim "arising in a foreign country") did not apply in leased areas. The court reasoned that since the Act constituted a waiver of the sovereign's immunity from suit, it should be narrowly construed. On appeal, ${ }^{59}$ the same court of appeals that decided the Vermilya-Brown case, after calling attention to the Supreme Court's affirmance of that decision, stated that although different statutes were involved, the prior decision was persuasive, if not "well-nigh conclusive," authority for reversal. The court found it difficult to believe that a base could be a possession under one act and foreign country under another. The Court concluded that "cession" of the area had actually been made. 60 It would seem, however, that the district court decision was consistent with the Vermilya-Brown case in construing the statute in the light of its policy, even though its decision did result in the same area being a possession under one act and foreign country under another, for the Supreme Court had merely decided that the area was a possession for the purpose of the particular statute before it. ${ }^{61}$ The court of appeals, on the other hand, based its decision on its own previous reasoning in the Vermilya-Brown case, ${ }^{62}$ and in fact reinforced its stand in actually stating that there has been cession of the area. ${ }^{63}$ This does not seem to conform to either the Supreme Court's rationale or to its determination that the area is foreign territory. ${ }^{64}$ It may be anticipated that further confusion will be added when similar cases come before the courts on the issue of whether these same statutes apply to areas in other categories.

Mr. Justice Jackson, speaking for the dissenters in the VermilyaBrown case, denied the existence of a question of statutory interpretation. His view is that the statute is clear in providing that it shall apply in any territory or possession of the United States, and thus it should be applied only to those places that are so regarded. Mr. Justice Jackson states the issue as being whether the Court will construe the lease agreement as adding the base to the United States' possessions. ${ }^{65}$ Examining

57. 75 F. Supp. 967 (E. D. N. Y. 1948). 1948).

58. 60 STAt. 843 (1946), as amended, 28 U. S. C. $\$ 2671$ et seq. (Cong. Serv.

59. Spelar v. United States, 171 F. 2d 208 (2d Cir. 1948).

60. Id at 209-210 (emphasis added).

61. Vermilya-Brown Co. v. Connell, 335 U. S. 377, 386 et seq. (1948).

62. See text at notes $40-41$ supra.

63. The court appears to have accepted the contention of the appellant's counsel who did not limit his argument to the point that the area was a possession for the purpose of the Tort Claims Act, but argued that the United States had in effect (if not in form) been ceded a possession. In comparing a case involving a ceded area with the instant case he argued, "the analogy . . . is almost perfect, except that in case of the Philippines the acquisition was by an instrument denominated as a treaty and in the case of the Newfoundland base the instrument was denominated as a lease. - . - certainly the fact that in one case acquisition was by lease and in the other by treaty is irrelevant." Brief for Appellant, pp. 7, 10, 11, Spelar v. United States, 171 F. 2d 208 (2d Cir. 1948).

64. Vermilya-Brown Co. v. Connell, 335 U. S. 377, 390 (1948).

65. Ibid. 
the limited rights acquired under the lease and the differences between leased areas and other areas long considered as possessions, the dissent concludes that the bases are by no means possessions, and that the Act therefore does not apply. In view of the dissenters' finding no question of statutory interpretation and the possibly greater justification for giving a more narrow construction to the Tort Claims Act than to the Fair Labor Standards Act, ${ }^{66}$ it would not be surprising if the Court reversed the decision in the Spelar case. ${ }^{66 \mathrm{~b}}$ The apparent lack of guides to aid the lower federal courts in their determination of these cases will probably result in inconsistent conclusions which eventually will have to be resolved by the Supreme Court.

\section{Trusteeship Territories}

In 1947, by means of a trusteeship agreement with the Security Council of the United Nations, ${ }^{87}$ the United States became the administering authority for 625 Pacific islands formerly held by Japan under mandate from the League of Nations. This agreement makes the United States the exclusive authority in these areas, with "full powers of administration, legislation, and jurisdiction over the territory ... and the United States] may apply to the Trust Territory . . . such of the laws of the United States as it may deem appropriate to local conditions and requirements." ${ }^{8}$ In addition, the United States has the right to close the islands to other countries whenever this country deems it expedient for security reasons. ${ }^{69}$ This agreement is not subject to amendment, alteration, or termination without the United States' consent. ${ }^{70}$ Thus it is a binding bipartite agreement rather than an arrangement terminable at the will of the Security Council. 71

It can readily be seen that jurisdiction and rights in these areas are much more comprehensive than those in the leased bases. The leased bases are held for the sole purposes of establishment and maintenance of military facilities. In the trust areas, although the principal American interest lies in the islands' strategic importance, ${ }^{72}$ there is not the same narrow limitation as in leased areas. No international complications need be anticipated, for instead of having two nations as parties to the agreement the United States and the Security Council are the parties. The effect is to place the United States in the peculiar position of being a party on both sides of the agreement. As a consequence, so long as the veto power exists, this country has the ability to prevent any com-

66. See Spelar v. United States, 75 F. Supp. 967,968 (E. D. N. Y. 1948).

66b. The Court has granted certiorari in United States v. Spelar, 17 U. S. L. WEEK 3312 (U. S. April 18, 1949).

67. Official Records of the Security Council, 2d Year, Supp. No. 8 at 69 (1947).

68. Art. 3, id. at 70.

69. Art. 13, id. at 73.

70. Art. 15 , id. at 74 .

71. See Official Records of the Security Council, 2d Year, No. 31 at 669-680 (1949). Mr. Gromyko, the Soviet delegate, offered an amendment which would permit the Security Council to alter or terminate the agreement. Mr. Austin on behalf of the United States commented that "it ought not to be accepted since the whole theory of the Trusteeship System is based on the fact that there must be, in any case, at least two parties to any Trusteeship Agreement. . . An amendment leaving the terms of an agreement and the power of termination to the Security Council alone is in violation of the Charter and of the theory of agreement." The amendment was not carried.

72. Hart, The United States and the Pacific Islands, 255 AnNals 115 (1948). 
plaint from ever being raised, although morally the American delegate may be bound not to invoke the veto.73

While it appears that little differentiation can be drawn between the status of these islands and that of owned areas, the Department of State does make a distinction. In answering the Attorney General's inquiry as to the status of a trust territory in reference to the Federal Tort Claims Act, the Legal Adviser of the Department of State replied that no treaty of cession has been signed ceding Saipan to the United States, no federal legislation has incorporated it into the United States, and this country does not have sovereignty over the area by virtue of the trusteeship agreement. The Legal Adviser therefore concluded that Saipan is not a part of the United States nor a territory or possession. ${ }^{74}$ Hence, this department considers nothing less than ownership and consequent sovereignty the requisites necessary for an area to achieve the status of a possession. Although the Department of State has not so stated, it appears that the United States exercises sovereignty without having it. This is analogous to American authority in the Panama Canal Zone. ${ }^{75}$

It is surprising that Brunell v. United States, ${ }^{76}$ decided in 1948, is the only case dealing with the applicability of federal statutes to trusteeship areas. At the time of this decision by the District Court for the Southern District of New York, the Court of Appeals for the Second Circuit had not yet reversed the Spelar case, nor had the Supreme Court affirmed the Vermilya-Brozen decision. The district court concluded that the Tort Claims Act did not apply to trusteeship territories. While this was consistent with the Spelar case prior to its reversal, it now puts this country in the position of having the same act in effect in an area which bears the lowest degree of similarity to an owned area, and not in effect in an area bearing the highest degree of similarity to an owned area. To be consistent, any statute which, because of its policy, is interpreted to apply to a leased base must at least apply to trust territories.

If the Supreme Court should continue to follow the Vermilya-Brozen reasoning in determining the applicability of statutes on the basis of the act's policy, it should at least eradicate the type of inconsistency raised by the Brunell case. The classification of the areas along the lines suggested by this Note might serve the purpose. There is no means, however, of predicting the way the courts will actually treat trust territories. Practically, they are owned areas; technically they most closely resemble the Panama Canal Zone, which itself has not been consistently dealt with; judicially, they have been given a status below that of leased areas; politically, they are not territories since Congress has not incorporated them, nor are they possessions since the United States does not own them-no treaty of cession having been signed.

\section{Occupied Areas}

There are but few precedents dealing with the legal status of occupied countries in relation to the United States. Most of the cases pertaining to the law of conquest deal with territory which has been ceded by the treaty.77 Two decisions of the Supreme Court however.

73. See Official Records of the Security Council, 2d Year, No. 31 at 669-680 (1947).

74. See Brunell v. United States, 77 F. Supp. 68, 70 (S. D. N. Y. 1948).

75. See text at notes 18-30 supra.

76. 77 F. Supp. 68 (S. D. N. Y. 1948).

77. E. g., Downes v. Bidwell, 182 U. S. 244 (1901) ; De Lima v. Bidwell, 182 U. S. 1 (1901). 
do deal with the status of occupied territory. In the earlier case of United States $v$. Rice, ${ }^{78}$ it was held that goods imported into the Port of Castine in the State of Maine, while occupied by the British, could not be taxed under the revenue laws as being goods imported into the United States. The Court reasoned that United States sovereignty was suspended and was vested in the British during the period of occupation. In the later case of Fleming $v$. Page, ${ }^{79}$ the factual situation was reversed. The United States had occupied the Port of Tampico in Mexico. The Court held that goods imported into the United States from Tampico were dutiable under revenue laws which applied to goods coming from "foreign countries." This famous case has been cited many times and is apparently settled law. On close examination, however, the case would seem to have been decided on practical policy rather than established law. The Court was careful first to state that, "As regarded all other nations, it [Tampico] was a part of the United States, and belonged to them as exclusively as the territory included in our established boundaries." 80 The Court could not see any justification for giving a conquered enemy the benefits of tax immunity which they would receive had the Court decided that Tampico was not foreign country. The Court's language is clear in indicating the policy: "The custom-house was established in an enemy's country, as one of the weapons of war. It was [not] established . . . for the purpose of giving to the people of Tamaulipas the benefits of commerce with the United States." 81 Thus, if the courts so desire, they can narrow the doctrine of Fleming v. Page to read, "For the purpose of the revenue acts, occupied areas are foreign countries." Under such an interpretation, other statutes, which by their terms do not apply in foreign countries, could be held to apply in conquered areas. ${ }^{82}$ In view of the importance seemingly placed on the presence or absence of sovereignty in many of the cases in this field, it is interesting to note that the Court in Fleming v. Page did say that Tampico was "undoubtedly at the time . . . subject to the sovereignty and dominion of the United States." 83

Recent decisions in the district courts have followed Fleming v. Page in holding the Federal Tort Claims Act inapplicable to occupied areas. ${ }^{84}$ However, these cases were decided prior to the Supreme Court's decision in the Vermilya-Brown case, the reasoning of which applies to occupied areas since this country has exclusive jurisdiction therein. Since there is jurisdiction, and since the customary statutory language is ambiguous, the Court in the Vermilya-Brown case reasons that it is the policy of the statute in question which will decide whether Congress intended it to apply to the area under consideration. Therefore, while the present district court decisions hold that the Tort Claims Act does not apply to occupied countries, it would not be inconsistent for other courts to hold that the act does apply, citing the Vermilya-Brown case for authority.

78. 4 Wheat. 246, 254 (U. S. 1819).

79. 9 How. 602 (U. S. 1850 ).

80. $I d$. at 615 .

81. Id. at 616 .

82. For judicial definitions of foreign country, see Burnet v. Chicago Portrait Co., 285 U. S. 1, 5 (1932); Pearcy v. Stranahan, 205 U. S. 257, 272 (1907); De Lima v. Bidwell, 182 U. S. 1, 180 (1901) ; Faber v. United States, 157 Fed. 140, 141 (C. C. S. D. N. Y. 1907).

83. 9 How. 603,614 (U. S. 1850).

84. Brewer v. United States, 79 F. Supp. 405 (N. D. Cal. 1948) ; cf. Straneri v. United States, 77 F. Supp. 240 (E. D. Pa. 1948). 


\section{CONCLUSION}

The difficulty, confusion, and inconsistencies resulting from statutes using the territories-and-possessions formula and the hardships caused by failure to classify the various categories of areas are apparent. No workable standards have been defined by which courts may arrive at consistent conclusions. A decision of one case will have little binding effect on another case having slightly different facts, and it is more than probable that the same act will be construed differently in the lower federal courts in the absence of a positive Supreme Court decision. Administrative agencies, which formerly relied upon the Department of State's determinations of the status of the areas, can no longer follow such rulings with any degree of certainty. While the political departments make tenuous distinctions between having sovereignty and exercising sovereignty, the courts have not addressed themselves to the genuine differences that do exist.

Drafters of federal legislation must be specific in designating the areas to be covered by the statutes. The courts in every case are attempting to find the legislative intent. Thus, initially, it is the legislators' duty to declare their intent in the clearest manner possible-trust territories are trust territories, and they should be stipulated as such in the statutes to dispel any possibility of confusion. Congress may even find it advantageous to designate subclassifications within the categories suggested by this Note. The statutes which were in effect prior to the acquisition of many of the categories of areas herein discussed should not be immune to change, for the fact that the acts are of long standing does not lessen the probability of confusion. Amendatory legislation must be undertaken; perhaps a special legislative drafting committee would be in order. The slight burden thus placed on the legislators will alleviate the present difficulties. Congress, with its investigatory facilities and close contact with the departments charged with the administration of the statutes and the areas in question, is best able to weigh the relevant international, political, social, and economic factors involved.

Should Congress be lax in addressing itself to this problem the courts should adopt a uniform policy of narrowly construing every statute. This will serve several purposes: (1) it will give to such a word as possessions a precise definition limiting its use to owned areas; $(2)$ the courts will achieve uniformity and consistency; and (3) it will force Congress to amend the statutes if it intends other areas to be covered. Such a policy, which has been followed by the courts in determining whether an owned area is incorporated, ${ }^{85}$ can as effectively be applied to the problem of determining the status of all noncontiguous areas.

$$
N . K \text {. }
$$

\section{Defamation-Absolute Privilege in Administrative Proceedings}

The law of defamation represents a regard for the protection of interests in reputation. ${ }^{1}$ Sometimes, however, the interest in reputation becomes less important for social well-being than the investigation of matters of public concern. On such occasions, it is desirable to free the

85. See text at note 9 supra.

1. See Laun v. Union Electric Co., 350 Mo. 572, 577, 166 S. W. 2d 1065, 1058 (1942); REsTatenent, ToRTS \$ 559 (1938). 
participants from the fear of civil actions against them for anything they may say or write in the course of the proceeding. ${ }^{2}$ The prime purpose is to encourage the best persons to undertake public office and responsibilities and to elicit the maximum amount of information on the subject at hand from the widest array of witnesses. ${ }^{3}$ Since the possibility of even a "nuisance action" may deter persons from bringing forward valuable testimony or otherwise participating in public proceedings, it would be inadequate to extend a merely conditional privilege 4 which would require one accused of defamation to show that the false statement was made in good faith. ${ }^{5}$ An absolute privilege is necessary, prohibiting any inquiry into the motives which prompted the statement. ${ }^{6}$ The grant of absolute privilege represents a judgment that the amount of true information gained thereby, outweighs the occasional wrong done by malicious abuse of the opportunity to injure someone's reputation. ${ }^{7}$ Traditionally, absolute privilege has been granted to judges, attorneys, parties, witnesses, and jurors in judicial proceedings, ${ }^{8}$ and to legislators ${ }^{9}$ and high executive officers ${ }^{10}$ in the exercise of their proper functions.

The rapid growth of the administrative device, in recent years, to perform public functions of great magnitude, makes absolute privilege an appropriate concept in connection with such proceedings. Inevitably the doctrine holds that the concept of absolute privilege is appropriate for a "quas1-judicial" 11 but not for a merely "administrative" 12 proceeding. ${ }^{13}$ As in most fields of law where labels become convenient devices for describing legal results, some courts have been led to a use of the label to reach the result. Meyer $v$. Parr ${ }^{14}$ may be instanced as an extreme example. There the court refused to privilege a letter written to a licensing board, seeking the revocation of an embalmer's license. After reciting the distinction to be drawn between proceedings judicial in nature and those purely administrative, the opinion notes that under the state constitution judges must be elected, and cannot be appointed. Since the presiding officials of the licensing board were appointees, the learned

2. Newelt, Slander and Liber $\$ 341$ (4th ed. 1924).

3. See Cochran v. Couzens, 42 F. 2d 783, 784 (D. C. Cir. 1930), cert. denied, 282 U. S. 874 (1930) ; Odgers, LIBEL AND SLANDER 187 (6th ed., Odgers \& Ritson, 1929).

4. See the introductory note to Restatement, ToRTs, c. 25, topic 2, tit. B (1938).

5. White v. Nicholls, 3 How. 266 (U. S. 1845); New York and Puerto Rico S. S. Co. v. Garcia, 16 F. $2 d 734$ (1st Cir. 1926).

6. Lea v. White, 4 Sneed 111 (Tenn. 1856); Neweld, Slander and Libel $\$ 350$ (4th ed. 1924).

7. See Guardian Life Ins. Co. v. Reagan, 140 Tex. 105, 113, 166 S. W. 2d 909, 913 (1942).

8. E. g., Adams v. Alabama Lime and Stone Corp., 225 Ala. 174, 142 So. 424 (1932) (libelous statement in complaint); see Royal Aquarium v. Parkinson, [1892] 1 Q. B. $431,442$.

9. Tanner v. Stevenson, $138 \mathrm{Ky} .578,128$ S. W. 878 (1910).

10. Glass v. Ickes, 117 F. $2 d 273$ (D. C. Cir. 1940), cert. denied, 311 U. S. 718 (1941) (Secretary of Interior); Mellon v. Brewer, 18 F. 2d 168 (D. C. Cir. 1927), cert. denied, 275 U. S. 530 (1927) (Secretary of Treasury).

11. Hasset v. Carroll, 85 Conn. 23, 81 Ati. 1013 (1911); McAlister \& Co. v. Jenkins, $214 \mathrm{Ky} .802,284$ S. W. 88 (1926) ; GatLey, Libel aNd Siander 186 (3d ed., O'Sullivan, 1938).

12. Blakeslee v. Carroll, 64 Conn. 223, 29 Atl. 473 (1894); Royal Aquarium v. Parkinson, [1892] 1 Q. B. 431.

13. See Restatement, Torts $\$ 585$, comment $c$ (1938).

14. 69 Ohio App. 344, 37 N. E. 2d 637 (1st Dist. 1941). 
court concludes that the proceedings cannot be said to be judicial in their nature.

Most courts, of course, have avoided such absurd reasoning. Though seldom expressly articulated, there seem to be two factors which adequately account for many cases, and commend themselves as a direct approach to the problem of granting or withholding absolute privilege: (1) the importance of the public function of the proceeding; ${ }^{15}$ and $(2)$ the adequacy of the procedural safeguards which will probably minimize the occurrence of defamatory statements. ${ }^{16}$

\section{The Public Interest}

Since absolute privilege is a concept designed to subordinate individual interests to the necessity of enlightened official action, it becomes increasingly appropriate as the importance of the issues increases. In many administrative proceedings the public interest is more directly concerned than in the average civil action in court.17 So far as function is relevant, therefore, each proceeding must be judged on its merits. The question has been litigated in recent years over a wide variety of matters, ranging from the Federal Communications Commission to local school boards.

Only a few categories of cases seem definitely established as uniformly privileged. In cases where awards are made, as in workmen's compensation proceedings, it is well-settled that absolute privilege prevails. ${ }^{18}$ Similarly, in matters involving the granting of charters, certificates of public necessity, and the licensing of professions, where honesty and competency are determinative factors and the consequences to the public are immediate and important, the trend is definitively toward the according of full privilege. ${ }^{10}$

In numerous other types of proceedings, however, no agreement is to be found in the cases. ${ }^{20}$ The factors which have been considered relevant in evaluating the relative social importance of the administrative task are varied, and sometimes of dubious significance. Thus, it has been con-

15. See Shumway v. Warrick, 108 Neb. 652, 189 N. W. 301 (1922) passim.

16. See the discussion by Judge Cardozo in Andrews v. Gardiner, 224 N. Y. 440, 121 N. E. 341 (1918).

17. See Rep. Atr'y Gen. Conrs. Ad. Proc. 19-20 (1941).

18. Simpson v. Oil Transfer Corp., 75 F. Supp. 819 (N. D. N. Y. 1948) ; Mickens v. Davis, 132 Kan. 49, 294 Pac. 896 (1931).

19. Duncan v. Atchison, 72 Fed. 808 (9th Cir. 1896) (libel in ICC hearings); Barton v. Rogers, 21 Idaho 609 , 123 Pac. 478 (1912) (libel before a school board); McAlister \& Co. v. Jenkins, $214 \mathrm{Ky} .802,248$ S. W. 88 (1926) (libelous statement before real estate board) ; Powers v. Vaughan, 312 Mich. 297, 20 N. W. 2d 196 (1945) (libel at a hearing for the purpose of granting a masseur's license); Alagna v. New York \& Cuba Mail S. S. Co., 155 Misc. 796, 279 N. Y. Supp. 319 (Sup. Ct. 1935) (letter in reference to FCC hearings); Hughes v. Bizzel, 189 Okla. 472, 117 P. $2 d 763$ (1941) (libel at a meeting of state university board of regents); Independent Life Ins. Co. v. Rodgers, 165 Tenn. 447, 55 S. W. $2 \mathrm{~d} 767$ (1933) (mandatory statement filed with insurance board).

20. Absolute privilege: Bolton v. Walker, 197 Mich. 699, 164 N. W. 420 (1917) (board of estimates); Nickovitch v. Mollart, 51 Nev. 306, 274 Pac. 809 (1921) (naturalization proceedings); Guardian Life Ins. Co. v. Reagan, $140 \mathrm{Tex} .105,166 \mathrm{~S}$. W. 2d 909 (1942) (statement filed with insurance board). Qualified privilege: Ranson v. West, $125 \mathrm{Ky} .457,101 \mathrm{~S}$. W. 885 (1907) (letter from school trustee to superintendent); Sweeney v. Higgins, $117 \mathrm{Me}$. 415, 104 Atl. 791 (1918) (board of aldermen); Aransas Harbor Terminal R. R. v. Taber, 219 S. W. 860 (Tex. Civ. App. 4th Dist. 1920) (hearing before railroad commission). 
sidered significant that the proceedings were not final, ${ }^{21}$ or that they were subject to de novo review, ${ }^{22}$ or that they did not include power to grant an award of relief, ${ }^{23}$ or that there was no power to subpoena witnesses. ${ }^{24}$

The realistic method of the better decisions may be illustrated by Shumway v. Warrick. ${ }^{25}$ There an applicant for a bank charter claimed to have been defamed by a letter to the state banking board, which accused him of malfeasance in a previous public office. In deciding the problem of privilege, the court discussed the nature of the banking board's function, citing the paramount public importance of granting charters only to persons of integrity, so that the funds of depositors would be reasonably protected. In order to encourage persons to come forward with information about applicants, therefore, it was advisable to free them from fear of any possible embarrassment through a civil action. Accordingly, the court sustained the defense of absolute privilege, holding that the purposes of the banking board were so important as to preclude any investigation into the motives of those appearing before it.

Since the same administrative agency may perform more than one function, absolute privilege may be denied in one proceeding before it, and be granted in another. It is the importance of public function which determines the matter, not the general nature of the agency. Charges of fraud against an insurance agent, for example, made to a licensing board of insurance commissioners, are fully privileged because of the importance of screening agents as to honesty, ${ }^{26}$ but a complaint to the same board, where the board's only function was to pass it on to competent authority, was held merely conditionally privileged, depending upon the good faith of the actor. ${ }^{27}$ The court apparently felt that the first function had considerably more importance than the second. ${ }^{28}$

\section{The Procedural Safeguards}

Since the public interest is more vitally concerned in many administrative proceedings than in a not inconsiderable proportion of courtroom actions, it might seem appropriate to extend a blanket immunity over all administrative actions, as is done for judicial proceedings. ${ }^{29}$ That this has not been done is in large measure to be attributed to the courts' distrust of the fairness of the administrative process. In a courtroom the proceedings are under the control of a judge trained in the common law rules of evidence, ${ }^{30}$ ostensibly schooled in the habit of judicial restraint, and

21. Proctor v. Webster, 16 Q. B. D. 112 (1885). note 21 .

22. Bleeker v. Drury, 149 F. 2d 770 (2d Cir. 1945); Proctor v. Webster, supra

23. Powers v. Vaughan, 312 Mich. 297, 20 N. W. 2d 196 (1945); Independent Life Ins. Co. v. Hunter, 166 Tenn. 498, 63 S. W. 2d 668 (1933).

24. Blakeslee v. Carroll, 64 Conn. 223, 29 Atl. 473 (1894); Aransas Harbor Terminal R. R. v. Taber, 219 S. W. 860 (Tex. Civ. App. 4th Dist. 1920).

25. 108 Neb. 652, 189 N. W. 301 (1922).

26. Independent Life Ins. Co. v. Rodgers, 165 Tenn. 447, 55 S. W. $2 d 767$ (1933); Guardian Life Ins. Co. v. Reagan, 140 Tex. 105, $166 \mathrm{~S}$. W. $2 d 909$ (1942).

27. Independent Life Ins. Co. v. Hunter, 166 Tenn. 498, 63 S. W. $2 d 668$ (1933).

28. These cases demonstrate the functional difference, but the basis of the latter decision is of doubtful validity. The denial of privilege to a complaint addressed to the wrong authority places too great a burden on the individual complainant to ascertain definitely the proper recipient, and deters the voluntary proffering of information.

29. Wilkins v. Hyde, 142 Ind. 260, 41 N. E. 536 (1895) ; Mannix v. Portland Telegram, 144 Ore. 172, 23 P. 2 d 138 (1933).

30. See Royal Aquarium v. Parkinson, [1892] 1 Q. B. 431, 447. 
equipped with the criminal sanctions against perjury and contempt with which to punish malicious statements. ${ }^{31}$ Judicial readiness to regard an administrative proceeding as entitled to absolute privilege tends strongly to increase as the measure of safeguards against the possibility of malicious statements is augmented. ${ }^{32}$ Nor is it always evident that the courts have allowed the importance of the agency's function to mitigate an unfavorable impression caused by the relaxing of procedural safeguards. The elements which have been considered by the cases are numerous.

Considerable attention is paid to the character of the presiding official. His training and outlook, measured by familiarity with the duties of a judge, ${ }^{33}$ are scanned on the theory that a competent moderator will be able to exclude much in the way of libelous statement. The sanctions available to him constitute one of the most important factors, and the power to administer oaths has been considered significant. ${ }^{34}$

Most weight has probably been given to a consideration of the general structure of the rules of evidence used by the agency in the proceeding in question. Application of the hearsay rules, rules of relevancy, and rules of materiality has been particularly noted. ${ }^{35}$ This concern for fairness is to be cherished, of course, so long as it fulfills the function of protecting against defamation. Since many of the evidentiary rules, however, have no relation to this function, it would be unwise to regard them as a basis for decision. It is not possible to decide from the cases how much the distinction has been honored, since there is a tendency toward wholesale condemnation in general language, of suspect procedure. ${ }^{36}$ It is submitted that many of the rules of evidence, moreover, are in the highest degree obstructive of the goal of obtaining the maximum amount of probative information, and have for that reason, and in view of the specialized knowledge of many administrative tribunals, been discarded. If the function of an agency requires the relaxing of some rules of evidence, and is sufficiently important, it is fallacious reasoning to deny absolute privilege because of the diminution of traditional procedural safeguards. In such cases, a delicate balancing of interests must be achieved, so that the full privilege is allowed if a decent minimum of orderly and rational procedure is present. Since the more important agencies tend to develop a considerable body of procedural rules, the balance can be struck.

Where the issues are ill-defined, or there are no pleadings, rules of relevancy cannot be applied, for lack of a yardstick. ${ }^{37}$ Since the discussion may range unchecked over a broad area, there is unusual opportunity to make malicious statements. Andrews v. Gardiner ${ }^{38}$ treats such a situation realistically. There counsel for a prisoner applying to a pardon board, made defamatory remarks about one who had been instrumental in convicting his client. In granting only conditional privilege, Judge Cardozo pointed out that the hearing procedure was highly informal, without defined issues or competent pleadings. He concluded, therefore, that it would be too dangerous to accord full privilege.

31. Veeder, Absolute Privilege in Defanation, 9 CoL. L. REv. 463, 486 (1909).

32. See the discussion in Rogers v. Thompson, 89 N. J. L. 639, 99 Atl. 389 (1916).

33. See Royal Aquarium v. Parkinson, [1892] 1 Q. B. 431, 447.

34. Nixon v. O'Callaghan, [1927] 1 D. L. R. 1152 (Ont. Sup. Ct. 1926), 41 Harv. L. Rev. 403, 404 (1928).

35. See Andrews v. Gardiner, 224 N. Y. 440, 447, 121 N. E. 341,343 (1918).

36. See Veeder, supra note 31 , at 486.

37. See Hale Co. v. Lea, 191 Cal. 202, 205, 215 Pac. 900, 901-902 (1923).

38. 224 N. Y. 440,121 N. E. 341 (1918). 
Aside from the importance of the observation of the rules of evidence, it is of special importance that the defamatory statement itself be relevant to the action. Whether or not the tribunal observes the rules of relevancy as a general rule, if the challenged remark is itself irrelevant, it will not be entitled to absolute privilege in American jurisdictions, ${ }^{39}$ exception being made for remarks by the judge in a courtroom proceeding. This requirement is not found in the English decisions, where relevancy has weight only as it affects the evaluation of the general practice of the agency with regard to procedural restrictions on evidence. ${ }^{40}$ What case law there is does not extend this privilege to irrelevant statements made by presiding officials in lay proceedings. ${ }^{41}$ Except for the feeling that judges are more likely to be circumspect than laymen, the distinction is hard to explain. As the era of professional administrators expands, it may be expected that the notion will wither.

Of necessity, the bounds of administrative actions may be more nebulous and wide-spread than in the orthodox common law action. It is desirable, therefore, to give a liberal interpretation to the question of relevancy. The reasonable limits of liberality may be exemplified by Colonial Stores $v$. Barrett. ${ }^{42}$ The defamatory statement was made in a certificate of availability for employment sent to a new employer of the plaintiff, pursuant to the requirements of the War Manpower Commission. The regulations of the Commission directed employers filing such statements not to enter remarks prejudicial to the employee in obtaining new employment, but the defendant nevertheless made the notation that the employee-plaintiff had been discharged as a trouble-maker. The court, denying privilege, pointed out that the purpose of the certificate was merely to certify that the employee was legally free to accept the new job, and that it was entirely volunteer for the old employer to inform the new employer of his opinion of the employee's qualifications. Indeed, the Commission's regulations showed that it wanted to discourage just such comments. Under the most liberal interpretation of relevancy, therefore, the statement failed to qualify.

Earlier cases often restricted privilege to statements in response to questions. ${ }^{43}$ More recently, however, the view has been abandoned, since information is to be welcomed from every source. ${ }^{44}$ Nor is the voluntary nature of an offer of evidence a circumstance against its reliability. Informal letters, for example, are entitled to the same privilege as testimony elicited by questioning at a hearing in response to subpoena.45 Any proper part of the proceeding is immune. Pleadings, ${ }^{46}$ depositions when introduced as evidence, ${ }^{47}$ instructions by the client to his attorney, ${ }^{48}$ peti-

39. Bartlett v. Christhilf, 69 Md. 219 (1888) (party); Hoar v. Wood, 3 Metc. 193 (Mass. 1841) (counsel); Calkins v. Sumner, 13 Wis. 193 (1860) (witness). Even where there is no absolute privilege, a qualified privilege attaches. Hyde v. McCabe, 100 Mo. 412, 13 S. W. 875 (1890); Nissen v. Cramer, 104 N. C. 574, 10 S. E. 676 (1889).

40. Munster v. Lamb, 11 Q. B. D. 588 (1883).

41. Blakeslee v. Carroll, 64 Conn. 223, 29 At1. 473 (1894).

42. $73 \mathrm{Ga}$. App. 839, 38 S. E. $2 d 306$ (1946).

43. E. g., Beggs v. McCrea, 62 App. Div. 39, 70 N. Y. Supp. 864 (1st Dep't 1901).

44. Independent Life Ins. Co. v. Rodgers, 165 Tenn. 447, 55 S. W. $2 d 767$ (1933).

45. Stafney v. Standard Oil Co., 71 N. D. 170, 299 N. W. 582 (1941); Higgins

v. Williams Pocahontas Coal Co., 103 W. Va. 504, 138 S. E. 112 (1927).

46. Baggett v. Grady, 154 N. C. 342,70 S. E. 618 (1911).

47. Mannix v. Portland Telegram, 144 Ore. 172, 23 P. 2d 138 (1933).

48. Zirn v. Cullom, 187 Misc. 241, 63 N. Y. S. $2 d 439$ (Sup. Ct. 1946) ; More v. Weaver, [1928] 2 K. B. 520. 
tions to the agency, ${ }^{49}$ and official reports ${ }^{50}$ are all privileged. Since the bounds of administrative action are not so well-defined as in courts of law, it seems desirable to accord liberal treatment to statements made at the inception or termination of administrative action. Thus, a letter to the Federal Communications Commission has been treated as a complaint, ${ }^{51}$ while a letter to a workmen's compensation commission challenging the fairness of an award was treated like a petition for rehearing. ${ }^{52}$ Comment to reporters following an unfavorable decision of the National Labor Relations Board, on the other hand, has been treated as entirely outside the bounds of the proceeding, and therefore unprivileged. ${ }^{53}$

\section{The Impact of Statutes}

In several jurisdictions, statutes grant absolute privilege to statements made in the proper discharge of official duty and in the course of any official proceedings authorized by law. ${ }^{54}$ Taken literally, these statutes would seem to render the whole of any governmental proceeding immune. The courts, however, have been reluctant to go so far. Submerged in the cases, the functional and procedural considerations which govern the nonstatutory decisions still seem determinative, although the statutes serve to liberalize the extension of the privilege. Under such statutes, proceedings before a university board of regents sitting on a faculty tenure hearing, ${ }^{55}$ and before a state athletic commission investigating bribery charges, ${ }^{50}$ have been held privileged, although in neither of these cases were there competent procedural safeguards.

The limits of the statutory application may be indicated by the denial of privilege to a letter written by a state director of a food analysis laboratory to his counterpart in a neighboring jurisdiction, condemning the quality of the plaintiff's product. ${ }^{57}$ Here the court laid emphasis on the fact that the letter was written purely voluntarily, was not an "official duty," and was not part of any pending proceeding. Since voluntary communications have been welcomed in other proceedings, it seems that the court was really influenced by lack of conviction of the importance of the function the defendant was performing, and regarded him as a mere meddler. The opinion also makes note of the lack of procedural safeguards in appraising the communication.

49. Guardian Life Ins. Co. v. Reagan, 140 Tex. 105, 166 S. W. 2 d 909 (1942).

50. Valesh v. Prince, 94 Misc. 479, 159 N. Y. Supp. 598 (Sup. Ct. 1916), aff'd, 224 N. Y. 613,121 N. E. 895 (1918); see Murray v. Brancato, 290 N. Y. 52, 55, 48 N. E. 2d 257, 259 (1943) ; cf. Irwin v. Ashurst, 158 Ore. 61, 74 P. $2 d 1127$ (1938) (broadcast of a trial held absolutely privileged).

51. Alagna v. New York \& Cuba Mail S. S. Co., 155 Misc. 796, 279 N. Y. Supp. 319 (Sup. Ct. 1935). (1927).

52. Higgins v. Williams Pocahontas Coal Co., 103 W. Va. 504, 138 S. E. 112

53. Washer v. Bank of America, 21 Cal. 2d 822, 136 P. 2d 297 (1943).

54. Car. Crv. Code $\$ 47$ (Deering, Supp. 1947) ; Mont. Rev. Codes $\$ 5692$ (1935); N. D. Rev. CoDE § 14-0205 (1943); OkLA. Stat., tit. 12, §1443 (1941); S. D. CodE $\S 47.0503$ (1939).

55. Hughes v. Bizzel, 189 Okla. 472, 117 P. $2 d 763$ (1941); Sanford v. Howard, 185 Okla. 660, 95 P. $2 d 644$ (1939).

56. Kelley v. Daro, 47 Cal. App. 2d 418, 118 P. $2 d 37$ (2d Dist. 1941).

57. Hale Co. v. Lea, 191 Cal. 202, 215 Pac. 900 (1923). 


\section{Conclusion}

Modern courts have generally recognized that absolute privilege is an appropriate concept for some types of administrative proceedings. In deciding whether to grant the privilege, the courts have looked chiefly to the importance of the administrative function and the adequacy of procedural safeguards. The latter criterion has sometimes been misapplied by requiring rules of evidence which do not tend to prevent defamation. Where statutes govern, the scope of protection has been extended, but not to the literal extreme possible under the broad wording usually found.

It is desirable to treat the administrative proceeding as sui generis, instead of forcing it into a traditional category from whose characteristics it markedly differs. Each proceeding, therefore, ought to be carefully considered on the merits of its function, peculiar requirements, and capabilities of improvement for protection of individual interests in reputation without seriously impairing its prime purpose. It would be unwise to grant a blanket extension of absolute privilege over the entire field. So long as the law protects reputation, the defense of privilege must be confined within the actual and ascertained bounds of public necessity. The delicate balance between the individual interest and the public need must be zealously maintained by constant judicial vigilance.

B. D. $H$.

\section{Rights of a Defaulting Plaintiff in Pennsylvania}

Subject to certain qualifications, a party who repudiates or defaults in the performance of contractual obligations is not entitled to maintain an action on the contract. Sometimes, though not always, he is also precluded from recovering in quasi contract for the benefits conferred upon the other party to the contract. ${ }^{1}$ In the latter case, whether recovery will be allowed or denied depends on many circumstances, such as the type of benefit the defaulting party has conferred, the extent of his performance, and the degree of fault involved. Thus a court will be more likely to grant recovery to a defaulting plaintiff who has parted with money or transferred a chattel, than to one who has furnished services. ${ }^{2}$ Furthermore, most courts will allow recovery for benefits conferred by a party who has defaulted inadvertently, but will deny recovery to a "willful" defaulter. ${ }^{3}$ These efforts, of course, manifest a judicial desire to avoid unjust enrichment which would result to one party were he allowed to retain the benefits conferred upon him by the defaulting plaintiff.

1. This Note will stress a defaulting plaintiff's rights in quasi contract. The action on the contract will be discussed only to the extent necessary to portray the present law in the light of its historical development. The outline followed is that suggested by Patterson, Restitution for Benefits Conferred by Party in Default under Contract in N. Y. Law Revision Consm'N REP. 195 (1942).

2. This distinction has a practical basis. Money and chattels are more easily returnable and likewise more easily valued, while personal services are not returnable in kind and their valuation is more difficult. See KEENER, QUASI-CoNTRACrs 227-228 (1893); WoOdWard, The LaW of QUasi Contracts $\$ 176$ (1913).

3. Restatement, Contracts $\$ 357$ (1932). Britton v. Turner, 6 N. H. 481 (1834), the first case to allow recovery by a willful defaulter, has been followed in only a few jurisdictions. 
The common law doctrine which has prevented a defaulting plaintiff from recovering on the contract is that of the condition precedent. ${ }^{4} \mathrm{~A}$ condition expressed in the contract must be exactly fulfilled; otherwise no liability can arise on the promise which it qualifies, because the validity of an express condition. depends on the manifested intention of the parties and hence has the same sanctity as the promise itself. ${ }^{5}$ By liberally interpreting the express condition, ${ }^{6}$ or by using a device such as the doctrine of waiver, ${ }^{7}$ however, courts avoid the more extreme cases of forfeiture. The doctrine of the condition precedent was extended in Kingston v. Preston, ${ }^{8}$ where it was announced that nonperformance of an implied condition relieves the other party from his duty to perform. This uncompromising doctrine, although championed as a sound instrument of justice by eminent legal writers, ${ }^{\circ}$ may entail severe hardship. The proposition that a failure to complete performance always bars recovery would lead to absurd results, and might considerably stifle business activity if carried to the extreme.10

To avoid these undesirable consequences, certain legal principles were developed. While their precise limits are not always easy to define, each aims at preventing forfeiture. The first mitigating doctrine to be developed was that of substantial performance. ${ }^{11}$ The general rule is that though a condition is not complied with, a plaintiff who has substantially performed may recover the contract price for his performance, less any amount necessary to compensate the defendant for failure to

4. Conditions in a contract may be expressed or implied. Implied conditions are commonly divided into those implied in fact and those implied in law. The demarcation line between express conditions and conditions implied in fact is shadowy, as is the line between conditions implied in fact and conditions implied in law. See Vold, Express Conditions in Contracts, 4 NEB. L. BuLL. 215 (1926). For a comprehensive discussion of the doctrine of conditions, see Corbin, Conditions in the Law of Contract, 28 YALE L. J. 739 (1919).

5. Diggs v. Taylor and Co., $329 \mathrm{~Pa}$ 385, 198 Atl. 51 (1938) ; Miller v. Reading Hotel Co., $248 \mathrm{~Pa}$. 541, 94 Atí. 225 (1915). An extreme judicial attitude toward express conditions in a contract is illustrated by Nelson v. Bonnhorst, $29 \mathrm{~Pa}$. 352 (1857), where the court held that if a defendant's promise is conditioned on his ability to pay, the plaintiff cannot recover unless he pleads and proves defendant's ability to pay. See Restatenent, Contracts $\$ \$ 252,258$ (1932); 3 Williston, Contracts $\S 669$ (rev. ed. 1936).

6. Mosser Co. v. Cherry River Co., 290 Pa. 67, 138 Ati. 85 (1927).

7. See Cape May Real Estate Co. v. Henderson, $231 \mathrm{~Pa} .82,86,79$ Atl. 982, 983 (1911). "The term waiver is one of those words of indefinite connotation in which our legal literature abounds; like a cloak it covers a multitude of sins." Corbin, supra note 4 , at 754 .

8. 2 Doug. 689, 99 Eng. Rep. 437 (K. B. 1773). The distinction drawn by Lord Mansfield between independent covenants, conditions precedent, and concurrent conditions has been adopted by REsTATEMENT, CoNTRACTS $\$ \$ 266-275$ (1932). For a discussion of constructive conditions, see Patterson, Constructive Conditions in Contracts, 42 Col. L. Rev. 903 (1942).

9. Keener, Quasi-Contracts 222-227 (1893) ; Woodward, The Law of QuasI Contracts $\$ 164$ (1913). Woodward's discussion is on the basis of assumption of risk rather than the condition precedent as used by Keener.

10. Williston believes that courts tend to find concurrent conditions whenever possible so as to avoid requiring either party to extend credit. 3 Wirliston, Contracrs $\S 835$.

11. The doctrine of substantial performance first appeared in the case of Boone v. Eyre, 1 Bl. H. 273, 126 Eng. Rep. 160 (C. P. 1777). The rules for determining the materiality of a failure to perform are found in RESTATEMENT, CoNTRACTS $\$ 275$ (1932). 
fulfill the condition. ${ }^{12}$ Obviously, only limited predictability can be achieved by a formula which depends on the content attributed to a term as indefinite as substantial. ${ }^{13}$ A second judicial device developed to temper the harshness of the condition precedent is the concept of severability of contracts. ${ }^{14}$ Its essential feature is that a party who has not completed performance of a divisible contract may nevertheless recover for each part he has fully performed. ${ }^{15}$ The doctrine's chief limitation, of course, is that as to each part the force of the condition predecent still applies, and to that extent forfeiture is still possible. Here, too, the vague contours of the term severable limit predictability.16

While the doctrines of substantial performance and severability may properly be regarded as exceptions to the rule that nonperformance precludes action on the contract, the doctrine of quasi contract is not an exception to that rule, but a separate principle, strictly speaking. ${ }^{17}$ The first two are rules of construction to be applied in a way that will avoid forfeiture; the third attacks the problem more directly. The action in quasi contract is not based on the defendant's promise, but on his unjust retention of benefits. ${ }^{18}$ The contract price has relevance only as the upper limit of recovery. Although there was ample historical antecedent in the Roman law, ${ }^{10}$ the doctrine did not find its place in the common law until Moses v. MacFerlan, ${ }^{20}$ and its development in this country has been slow and uneven. The law of quasi contract, nevertheless, is thought to be better adapted to attain equality and uniformity than the other mitigating doctrines referred to above. By its more direct approach, the theory of quasi contract avoids the necessity inherent in the other two doctrines of giving strained constructions to the contract.

12. See Ballantine, Forfeiture for Breach of Contract, 5 MINN. L. Rev. 329, 330333 (1921). The doctrine of substantial performance is chiefly applied in the field of building contracts. It is also extensively applied to construction contracts requiring architects' certificates of satisfactory performance. In Pennsylvania, production of such a certificate is a condition precedent to recovery even though there has been substantial performance. Bush v. Jones, 144 Fed. 942 (3d Cir. 1906) ; Adinolfi v. Hazlett, $242 \mathrm{~Pa}$. 25, 88 Atl. 869 (1913).

13. Williston criticizes the doctrine of substantial performance, insisting that it is better to avoid hardship of this sort by allowing recovery in quasi contract than to set aside an agreement of the parties, since when confessedly enforcing an obligation imposed by law the court may fairly fix such boundaries as justice requires. 3 WILLISTON, CONTRACTS $\$ 805$.

14. A contract is said to be divisible when the whole performance is divided into two sets of partial performances, each part of each set being equivalent to a corresponding part of the set of performances to be rendered by the other promisor. See Restatement, Contracts $\$ 266(3)$ (1932); 3 Williston, Contracts $\$ 860 \mathrm{~A}$.

15. See McGowan, The Divisibility of Employment Contracts, 21 Iowa L. Rev. 50 (1935). Compare Gill v. Johnstown Lumber Co., 151 Pa. 534, 25 A.t1. 120 (1892), with Shires v. O'Connor, 4 Pa. Super. 465 (1897).

16. See Ballantine, supra note 12 , at 338.

17. See Patterson, The Scope of Restitution and Unjust Enrichment, 1 Mo. L. Rev. 223 (1936).

18. The plaintiff, however, must offer some explanation as to how he conferred the benefit on the defendant; otherwise he will appear in court as a meddler and recover nothing. The explanation, therefore, will bring in the terms of the contract. See RESTATEMENT, RESTITUTION \$2 (1937). Woodward has criticized the use of the term unjust enrichment as being too narrow a formulation of the quasi contractual obligation, insisting that the receipt of benefits is sufficient. WOODWARD, THE LAW OF QUASI CONTRACTS \& 8 (1913).

19. DigEst 44.7.5 indicates that quasi contract, as a division of private law, was developed to denote obligations which arose neither out of contract nor out of tort.

20. 2 Burr. 1005, 97 Eng. Rep. 676 (K. B. 1760). 
It is the purpose of this Note to set forth the extent to which a defaulting plaintiff is allowed in Pennsylvania to recover in quasi contract as compared with other possible forms of contractual relief.

\section{The Status of the Law in Pennsylvania}

Employment or Personal Service Contracts.-The majority of jurisdictions in the United States hold that where an employee willfully defaults in the performance of his contract, he cannot recover either in an action on the contract or in quasi contract. ${ }^{21}$ This view is supported by the Restatement of Contracts ${ }^{22}$ and by many legal writers. ${ }^{23}$ The opposition is led by the much mooted case of Britton v. Turner. ${ }^{24}$ There the plaintiff, a farm hand, had contracted to work for one year for a total compensation of $\$ 120$; although he quit unjustifiably after nine and a half months, he was allowed to recover on a quantum meruit count the reasonable value of his services, or ninety-five dollars, his employer having suffered no damage. ${ }^{25}$ The decision has been both severely criticized ${ }^{26}$ and strenuously defended. ${ }^{27}$ The flood of comments which it provoked ${ }^{28}$ makes it superfluous to recite here the arguments advanced either for or against it. The gravamen of those who defend the "majority" or common law rule is that a willful defaulter deserves no sympathy, and that to permit him to recover with impunity would be to encourage breaches of contract. ${ }^{29}$ The advocates of the minority rule claim that such a mechanical denial of any compensation to a willful defaulter would often result in forfeitures, and would introduce into the law of contract the alien and totally unwarranted concept of punitive damages. ${ }^{30}$ The controversy is still very much alive today despite efforts at compromise. ${ }^{31}$

21. See Woodward, The LaW of Quasi Contracts $\$ 174$ n. 1 (1913).

22. $\$ 357(1)$.

23. See KeEner, Quasi-Contracts 218-225 (1893); Woodward, The Law of Quasi Contracts $\S 172$ (1913); Ashley, Britton v. Turner, 24 Yale L. J. 544 (1915). See also 5 WILLISTON, Contracts $\S 1477$.

24. 6 N. H. 481 (1834).

25. This decision has been followed directly or approved through dicta by some eleven jurisdictions. See Patterson, Restitution for Benefits Conferred by Party in Default under Contract in N. Y. LAw REvision CoMm'N REP. 195, 216 (1942).

26. See note 23 supra.

27. See Laube, The Defaulting Employee-Britton v. Turner Re-vieved, $83 \mathrm{U}$. of PA. L. REv. 825 (1935) ; Laube, The Right of an Employee Discharged for Canse, 20 MrNs. L. Rev. 597 (1936) ; Mulder, The Defaulting Plaintiff in North Carolina, 15 N. C. L. REv. 255 (1937) ; Note, 24 CoL. L. REv. 885 (1924). For an extensive review of the law in New York, see Patterson, Restitution for Benefits Conferred by Party in Default under Contract in N. Y. LAW REvision Coma'N REP. 195 (1942).

28. For an interesting and lively exchange of opposite stands on the subject, see Laube, The Defaulting Employee-Britton v. Turner Re-viewed, 83 U. of PA. L. Rev. 825 (1935); Williston, The Defaulting Employee-A Correction, 84 id. at 68 (1935); Laube, $N o$ Retraction, 84 id. at 69 (1935).

29. Woodward, in criticizing the decision of Britton v. Turner, says, "Considerations both of policy and justice forbid its approval. One whose hands are soiled by willful wrongdoing is hardly in a position to complain. Better far that the innocent defendant should profit by the breach than that the guilty plaintiff should be given a remedy in spite of it." WOODWARD, ThE LAW OF QUASI CONTRACTS \$ 272 (1913).

30. The longer the plaintiff works the greater would be his penalty and the more unjust would be the benefit to the defendant. Furthermore, where the defendant has suffered no loss he would be receiving benefits in excess of the amount of damages he could collect if he had brought suit for breach of contract. Laube. The Defaulting Employee-Britton v. Turner Re-viewed, 83 U. of PA. L. REv. 825, 835 (1935).

31. See McGowan, supra note 15, at 56, suggesting that where there appears to be great forfeiture, the courts might elect to treat the contract as severable and allow the plaintiff to recover for each completed part. 
At any rate, it is significant to note that in the cases where the employer wrongfully discharges his employee, it is uniformly held that the latter can only recover the actual damages he has suffered, $i$. $e$., the wages due him for the unexpired term of the employment, less what he earned or could have earned elsewhere. ${ }^{32}$ On the other hand, if the employee willfully abandons his work he can recover nothing, according to most courts, whether or not the employer was damaged. To this extent the two rules appear inconsistent, therefore, since the measure of liability of the guilty employer is reparation, while the measure of liability of the guilty employee may often be forfeiture.

In the main, the Pennsylvania courts have followed the common law rule of denying recovery to a willfully defaulting employee. Since most cases arose before quasi contractual principles were generally accepted in Pennsylvania, and since in many cases there is no indication that quantum meruit was pleaded, the decisions being based on a contract count, one may say that they are not precedents for denying recovery in quasi contract. Many of the opinions, however, leave no doubt as to the attitude of the courts toward willful defaulters. The earliest case found is $M c$ Dowell $v$. Ingersoll. ${ }^{33}$ There the plaintiff, engaged to survey a body of land, left inexplicably without completely performing in the manner prescribed by statute. The plaintiff sued in indebitatus assumpsit. The court denied recovery, holding that the plaintiff, having voluntarily left without fully performing an "entire" contract, could not recover anything either as fees under the statute or as compensation on principles of common law. In a later case, the court again denied recovery to a plaintiff who quit his contract to haul wood before he had finished, commenting that there was no moral obligation to compensate for the labor of a man who has deliberately cut himself loose from part of his bargain. ${ }^{34}$ The court quoted with approval Mr. Justice Brackenridge in Woods $v$. Ingersoll, ${ }^{35}$ where he said, "We can form no idea of a quantum meruit for half services." Later cases evince the same judicial attitude and reasoning. ${ }^{36}$ Recovery has sometimes been allowed, however, on the ground that the defendant accepted the part performance, thus waiving or excusing the plaintiff's wrong. ${ }^{37}$ Some lower courts' opinions show a tendency to relax the strict common law rule by interpreting the contract more liberally. ${ }^{38}$

At common law, an employee serving under an entire contract could not recover for services rendered if he was discharged justifiably before

32. The employer can mitigate his damages if he can show that the employee, upon discharge, obtained or by the exercise of reasonable effort could have obtained, similar or comparable employment elsewhere. Russel v. Barnes Foundation, 52 F. Supp. 827 (E. D. Pa. 1943), aff'd, 143 F. 2d 871 (3d Cir. 1944), cert. denied, 323 U. S. 771 (1944) ; Emery v. Steckel, 126 Pa. 171, 17 Atl. 601 (1889).

33. 5 S. \& R. 101 (Pa. 1819).

34. Harris v. Ligget, 1 W. \& S. 301 ( $\mathrm{Pa} .1841$ ).

35. 1 Binn. 146, 151 ( $\mathrm{Pa}$. 1806).

36. E. g., Schotter v. Carnegie Steel Co., 272 Pa. 437, 116 Atl. 358 (1922); Shafer v. Senseman, $125 \mathrm{~Pa} .310$, 17 Atl. 350 (1889) ; Pottsville Iron and Steel Co. v. Good, $116 \mathrm{~Pa}$. 385, 9 Atl. 497 (1887). 1892)

37. Fessler v. Love, 43 Pa. 313 (1862) ; Green v. Green, 16 Pa. County 392 (C. P.

38. In Baskow v. Sliver, $95 \mathrm{~Pa}$. Super. 247 (1929), plaintiff quit his painting and paperhanging job before completion. The court sustained a verdict for the plaintiff, saying that the contract was entire but as the finding was for an amount less than the balance claimed by the plaintiff, the verdict would not be disturbed. See also Ely v. Waln, 1 Weekly Notes of Cases 248 (Pa. C. P. 1875) ; Stilely v. Walker, 1 Pitt. Legal J. 98 (Pa. C. P. 1853). 
the end of the term, the rationale being that an employee who has broken a contract has no rights under it. ${ }^{39}$ American decisions show a division of opinion on the question. ${ }^{40}$ It is said, however, that the modern or American rule has largely superseded the ancient one and that the employee is allowed to recover in quasi contract for services actually rendered, less any damage to the employer, ${ }^{41}$ provided the employee was not discharged because of gross misconduct or dishonesty. ${ }^{42}$ The Pennsylvania cases in this category exhibit little consistency. In the main, the courts seem to have been influenced by the degree of plaintiff's culpability, ${ }^{43}$ ignoring the fact that they may thereby be permitting defendant's unjust enrichment. Indeed, one case holds that a servant guilty of a criminal offense noninjurious to the employer can recover no wages due him.44 Other cases show a less drastic judicial attitude, even though the employee was justifiably discharged for disobedience, ${ }^{45}$ incompetence, or neglect. ${ }^{46}$ The employee, under this view, loses only the right to receive wages for the remainder of the agreed term. ${ }^{47}$ This can hardly be called a forfeiture, since the employee is simply losing part of his bargain and not the value of the services he actually rendered. A remarkably liberal attitude is shown in the case of Geraghty $v$. Pitcairn. ${ }^{48}$ Despite the court's holding that the contract was entire, plaintiff, rightfully discharged at the end of thirteen months of service in a contract running for fifteen months, was allowed to recover the proportional amount of a bonus which was not part of the regular salary but was due at the termination of the contract. Recovery was on the contract; the court said that while a person dismissed for cause cannot sue on a quantum meruit, his recovery must be on a quantum meruit on the contract basis.

The willingness of courts to avoid forfeiture and to perform substantial justice is shown by the greater recognition recently given to the doctrine of severability of contract. ${ }^{40}$ It has been suggested that the de-

39. Turner v. Robinson, 5 B. \& Adol. 789, 110 Eng. Rep. 982 (K. B. 1833) ; see 2 Parson, Contracts 42 (8th ed. 1883).

40. See Woodward, The LaW of Quasi Contracts $\$ 174$ (1913).

41. See Wood, Master \& Servant $\$ 129$ (2d ed. 1905); Laube, The Right of an Employee Discharged for Cause, 20 MrNN. L. Rev. 597 (1936).

42. 5 WIILISTON, Contracts $\$ 1477$. Woodward suggests that good faith should be the test for allowing or denying recovery. WOODWARD, THE LAW OF QUASI CoNTRACTS $\$ 174$ (1913).

43. Ulrich v. Hower, $156 \mathrm{~Pa}$. 414, 27 Atl. 243 (1893) (drunkenness); Waugh v. Shunk, $20 \mathrm{~Pa} .130$ (1852) (failure to exercise purported skili); Heck v. Shener, 4 S. \& R. 249 (Pa. 1818) (bad faith of housekeeper) ; Hibbard v. Wood, 49 Pa. Super. 513 (1912) (lack of fidelity to employer).

44. Libhart v. Wood, 1 W. \& S. 265 (Pa. 1841).

45. Peniston v. John Huber Co., 196 Pa. 580, 46 At1. 934 (1900) ; Gallagher v. Wayne Steam Co., 188 Pa. 95, 41 Atl. 296 (1898); Matthews v. Park Bro's, 159 Pa. 579, 28 Atl. 435 (1894) ; Carson v. West Branch Hosiery Co., 15 Pa. Super. 476 (1900).

46. Lubriko Co. v. Wyman, 290 Fed. 12 (3d Cir. 1923) ; Elliot v. Wanamaker, 155 Pa. 67, 25 Atl. 826 (1893).

47. Gallagher v. Wayne Steam Co., 188 Pa. 95, 41 At1. 296 (1898) ; Matthews v. Park Bro's, 159 Pa. 579, 28 Atl. 435 (1894); Lightcap v. Keaggy, 128 Pa. Super. 348, 194 At1. 347 (1937).

48. 104 Pa. Super. 72, 157 At1. 634 (1931).

49. Peniston v. John Huber Co., $196 \mathrm{~Pa}$. 580, 46 Atl. 934 (1900) ; Gill v. Johnstown Lumber Co., $151 \mathrm{~Pa} .534,25$ Ati. 120 (1892). But cf. Pitcairn v. Philip Hiss Co., 107 Fed. 425 (C. C. W. D. Pa. 1901) ; Shires v. O’Connor, 4 Pa. Super. 465 (1897). See 3 WrLliston, Contracts $\$ 862$. 
vice of severability could provide the legal weapon for those courts which refuse to grant recovery on a quasi contractual basis but would be willing to avoid unjust enrichment and forfeiture by the use of a concept more consistent with the traditional common law rules of contract. ${ }^{50}$ The wide enactment of wage statutes requiring payment of wages at specified intervals would seem to make the task easier. The Pennsylvania statute provides for payment to employees semimonthly. ${ }^{51}$ This, it is thought, has the effect of fastening divisibility on a personal service contract regardless of the intent of the parties. The effect of the statute is limited, however, since it does not apply to all types of employees 52 or to cases where the parties have stipulated differently in the contract. ${ }^{53}$

Construction Contracts. ${ }^{54}$-In many jurisdictions, a builder who negligently defaults in the performance of his contractual obligation may recover in quasi contract the reasonable value of his labor and materials, less the damage caused by the breach. ${ }^{55}$ In Pennsylvania, perhaps because no quantum meruit count appeared in the declaration, no specific case has been found allowing a builder in default to recover on a quasi contractual basis, but the language of some decisions seems to indicate that this is the basis for recovery. In Wade v. Haycock, for example, recovery was allowed in an action of debt for a partially defective mill built by the plaintiff. The court said that where the work is well done but partially defective there may be a recovery of the contract price, or in the absence of a contract, what the work is reasonably worth, less damages for defects. ${ }^{56}$ However, no recovery can be had either on the contract or in quasi contract where there has been merely partial performance. $^{57}$ This holds true even if the work has been of some value to the defendant, ${ }^{58}$ unless the builder was prevented from completing the project by the action of the other party, ${ }^{59}$ or by impossibility of performance, ${ }^{60}$ or because the partial performance was accepted by the defendant so as to constitute a waiver of the condition to perform fully. ${ }^{61}$ Likewise,

50. McGowan, supra note 15 , at 53 .

51. PA. Stat. AnN., tit. 43, § 251 (Purdon, 1941).

52. Commonwealth v. Marsh, 14 Pa. County 369 (Q. S. 1894).

53. Martin's Complaint, 41 Pa. County 647 (C. P. 1913).

54. The distinction drawn between construction and employment contracts is perhaps arbitrary, and some of the cases cited under one heading may properly fall under the other. In construction contracts, the plaintiff does not necessarily perform the work himself, but employs other people.

55. Pinches v. Swedish Church, 55 Conn. 183, 10 Atl. 264 (1887) ; Eckes v. Luce, 70 Okla. 67, 173 Pac. 219 (1917); Woodford v. Kelly, 18 S. D. 615, 101 N. W. 1069 (1904).

56. 25 Pa. 382, 383 (1855) ; accord, Smith, Trustee v. Cunningham Piano Co., 239 Pa. 496, 86 Atl. 1067 (1913) ; Moore v. Carter, 146 Pa. 492, 23 Atl. 243 (1892) ; Pepper v. Philadelphia, 114 Pa. 96, 6 Atl. 899 (1886); Brown v. Philadelphia, 3 Sadier 45, 6 At1. 904 ( $\mathrm{Pa} .1886$ ).

57. Frank v. Allegheny County, 119 F. 2d 614 (3d Cir. 1941), citing Crawford v. McKinney, 165 Pa. 609, 30 Atl. 1047 (1895); McClurg v. Price, 59 Pa. 420 (1868).

58. Bryant v. Stilwell, $24 \mathrm{~Pa}$. 314 (1855) ; Danville Bridge Co. v. Pomroy, 15 Pa. 151 (1850) ; Sturts v. Ziegler, $44 \mathrm{~Pa}$. Super. 124 (1910).

59. Cramp \& Co. v. Central Realty Corp., 268 Pa. 14, 110 At1. 763 (1920) ; Hayer Bro's Construction Co. v. American Sterilizer Co., 258 Pa. 217, 101 At1. 1002 (1914). 60. Hottinger v. Hoffman-Henon Co., $303 \mathrm{~Pa} .283$, 154.Atl. 598 (1931); Busse v. Center Twp. School Dist., 53 Pa. D. \& C. 479 (C. P. 1948).

61. Watkins v. Neff, $288 \mathrm{~Pa}$. 314, 136 Atl. 221 (1927) ; Otis Elevator Co. v. Flanders Realty Co., 244 Pa. 186, 90 Atl. 624 (1914). But cf. Hartupee v. Pittsburgh, $97 \mathrm{~Pa} .107$ (1881) ; Miller v. Philips, $31 \mathrm{~Pa} .218$ (1858). 
a contractor who willfully abandons performance before completion or willfully departs from the provision of the contract cannot recover, since good faith and an honest endeavor to perform fully are requisite for recovery. ${ }^{62}$ This is consistent with the courts' attitude toward willful defaulters, much as that may be at variance with quasi contractual principles of awarding reasonable compensation for benefits conferred.

The method most widely used in this country for allowing recovery on a construction contract partially performed is the doctrine of substantial performance. The rule that one must perform completely before he can recover is relaxed where the performance is so far perfected as to fulfill the intended purpose of the contract. ${ }^{63}$ The aim of the doctrine is to secure substantial justice in proper cases by relaxing the rigid and sometimes harsh rule as to "entire" contracts, without at the same time departing from the traditionally accepted body of common law rules. ${ }^{64}$ Relief is given because in construction contracts it may be almost impossible to avoid slight defects or omissions despite the most diligent efforts, and also because the builder, who would otherwise suffer great loss, cannot be restored to his former position by the owners. ${ }^{65}$ In Pennsylvania, the doctrine is construed rather strictly. The first requisite for its application is that the default must not be too great either as to character or magnitude; the question is one for the jury ${ }^{60}$ unless the variance is great, in which case it is the duty of the court to give binding instructions for defendant. ${ }^{67}$ Good faith and an honest endeavor fully to perform are required, allowance being made only for minor defects or

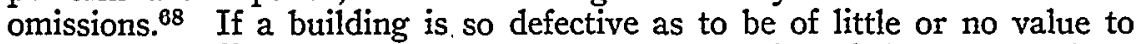
the defendant, ${ }^{69}$ or if it is not made to the satisfaction of the owner, whose objections are genuine, or if there is a material departure from the provisions of the contract, ${ }^{70}$ no recovery can be had. Likewise, the question of substantial performance will not be submitted to the jury if there has. been a willful omission or departure from the contract terms. ${ }^{71}$ The courts are emphatic in saying that recovery for substantial performance is impossible if one unjustifiably abandons the work. Even if abandonment was in good faith, there can be no recovery if the plaintiff's failure to

62. Shaw v. The Turnpike, 2 P. \& W. 454 (Pa. 1831) ; A. C. Denahan \& Co. v. Holmesburg Granite Co., 45 Pa. Super. 399 (1911).

63. E. g., Sgarlat v. Griffith, 349 Pa. 42, 36 A. 2d 330 (1944), reversing $152 \mathrm{~Pa}$. Super. 233, 31 A. 2d 555 (1943) ; Pressey v. McCormack, 235 Pa. 443, 84 Atl. 427 (1912); Monocacy Bridge Co. v. American Iron Bridge Mfg. Co., 83 Pa. 517 (1877); Typhoon Air Conditioning Co. v. Fried, 147 Pa. Super. 605, 24 A. $2 d 926$ (1941).

64. The doctrine is regarded as equitable. See Corbin, Conditions in the Law of Contract, 28 YALE L. J. 739, 758-763 (1919). (1921).

65. See Ballantine, Forfeiture for Breach of Contract, 5 Mins. L. Rev. 329, 331

66. Pressey v. McCormack, 235 Pa. 443, 84 Atl. 427 (1912).

67. Harris v. Sharples, 202 Pa. 243, 51 Atl. 965 (1902).

68. Otis Elevator Co. v. Flanders Realty Co., 244 Pa. 186, 90 Atl. 624 (1914); White v. Braddock School Dist., 159 Pa. 201, 28 Atl. 136 (1893) ; Moore v. Carter, $146 \mathrm{~Pa} .492,23$ Atl. 243 (1892) ; Sticker v. Overpeck, $127 \mathrm{~Pa}$.446, 17 Atl. 1100 (1889); Typhoon Air Conditioning Co. v. Fried, 147 Pa. Super. 605, 24 A. 2d 926 (1941).

69. Miller v. Philips, 31 Pa. 218 (1858).

70. Morgan v. Gamble, 230 Pa. 165, 79 Atl. 410 (1911); Singerly v. Thayer, 108 Pa. 291, 2 At1. 230 (1895).

71. Gillespie Tool Co. v. Wilson, 123 Pa. 19, 16 Atl. 36 (1888); Shaw v. The Turnpike, 2 P. \& W. 454 (Pa. 1831); A. C. Denahan \& Co. v. Holmesburg Granite Co., 45 Pa. Super. 399 (1911). 
complete the work was not due to any fault of the defendant. ${ }^{2}$ The measure of recovery where relief is granted is determined by the contract price as the upper limit, the amount being the difference between the value of the work as turned over to the defendant and what it would cost him to have it completed according to the original contract. ${ }^{73}$ It appears, therefore, that many cases cannot be brought within the doctrine even if it is liberally applied, and that forfeiture will often result by denying any relief to a plaintiff materially in default. The attitude of punishing a willful breacher often results in an arbitrary, automatic forfeiture, especially where the agreed performance is nearly finished. A greater recognition and application of quasi contractual principles would go far toward eliminating the shortcomings of the doctrine of substantial performance. ${ }^{74}$

Contracts for the Sale of Goods.-Since its enactment, the Uniform Sales Act has regulated the rights and liabilities of a defaulting seller of chattels. ${ }^{75}$ Even before the Act's adoption, Pennsylvania courts accepted the rule that a seller can recover if he partially performs his contract. ${ }^{76}$ In Badger $v$. Shaze ${ }^{77}$ a quasi contractual recovery was allowed for cattle sold to the defendant, although the plaintiff seller had defaulted in the full performance of his contract by failing to deliver some sheep included in the same bargain. It is said that one reason for allowing a seller in default to recover for part performance is that the buyer is often in a position to make restitution in specie, which is not true of employees and building contractors. ${ }^{78}$ No distinction is made in this class of cases between a willful and a merely inadvertent default. This is attacked as an inconsistency by those legal writers who have protested the application of this distinction to defaulting employees and builders. ${ }^{79}$ Section 44 of the Uniform Sales Act ${ }^{80}$ codifies the rule allowing recovery to a seller in default if the buyer has accepted or otherwise been benefited by the goods received. If the buyer knows that the seller will not perform fully but does not reject the goods he must pay the contract price for them. ${ }^{81}$ Section 44 apparently adopts a quasi contractual measure of damages where the buyer accepts and disposes of the goods without such knowledge, since the seller may then recover the reasonable value of the goods to the buyer. ${ }^{82}$

72. In re Carson's Estate, 349 Pa. 529, 37 A. 2d 488 (1944).

73. Moore v. Carter, $146 \mathrm{~Pa}$. 492, 23 Atl. 243 (1892); Sticker v. Overpeck, 127 Pa. 446, 17 Atl. 1100 (1889); Ellis v. Lane, $85 \mathrm{~Pa} .265$ (1877). In some jurisdictions recovery for substantial performance is on a quantum meruit basis. E. g., Foeller v. Heintz, 137 Wis. 169,118 N. W. 543 (1908).

74. See note 13 supra and text.

75. PA. Stat. ANN., tit. 69, \$254.1 (Purdon, 1931).

76. In Meyercord Co. v. P. H. Butler Co., 79 Pa. Super. 473 (1922), the court said that the Act was merely declaratory of existing Pennsylvania law.

77. 12 S. \& R. 275 ( $\mathrm{Pa}$. 1825).

78. WoOdWard, THE LaW OF QUasi Contracts \& 176 (1913).

79. Laube, The Defaulting Employee-Britton v. Turner Re-viewed, 83 U. of PA. L. REV. 825 (1935).

80. PA. STAT. ANn., tit. 69, §254.1 (Purdon, 1931).

81. The partial delivery is said to constitute a new offer, and the retention of goods by the buyer operates as a severance of the contract. 2 WIILISTON, SALES $\S 460$ (rev. ed. 1948); 5 WIILISTON, ConTracts $\$ 1474$. As to the rights of a buyer to reject the goods, see Honnold, Buyer's Right of Rejection, 97 U. OF PA. L. Rev. $457(1949)$.

82. See 2 Williston, Sales $\$ 460$ (rev. ed. 1948). The Pennsylvania cases decided under this section of the Act do not shed much light as to how the courts may interpret it. 
In contrast to the rights of a defaulting seller to recover on a partially performed contract, a defaulting buyer who has paid part of the purchase price is denied, according to Pennsylvania case law, recovery for any money so advanced, ${ }^{83}$ the Uniform Sales Act being silent on the point. One may speculate whether a different result would be reached if a substantial amount were advanced; no cases have been found squarely presenting the question. In some jurisdictions the buyer is allowed restitution, at least where no provision for forfeiture is made in the contract. ${ }^{84}$ While in many cases recovery would properly be denied because the damages caused to the seller by the buyer's default equal or exceed the sum advanced by the buyer, the courts seldom use this criterion. They say, instead, that a plaintiff in default cannot recover against one not in default.85 Even where the buyer's default enabled the seller to profit by reselling the merchandise at a higher price, the plaintiff has not been permitted to recover his advances. ${ }^{86}$ As in the case of the defaulting seller, no distinction is made between a buyer who is willfully in default and one who is not, although the element of willfullness would seem to be more apparent in sales contracts than in the cases of employment or building contracts. ${ }^{87}$ The Pennsylvania Conditional Sales Act ${ }^{88}$ provides that a buyer under a conditional sale contract who has paid fifty per cent or more of the purchase price before the seller retakes the goods, is entitled to recover the amount in excess of the seller's damages and expenses of resale. ${ }^{89}$

Contracts for the Sale and Purchase of Realty.-The Pennsylvania courts have consistently held that where a vendor defaults in the performance of his contract to convey after the vendee has paid part of the purchase price, and this failure is not due to bad faith or fraud, a vendee who is not himself in default may rescind the agreement and recover the amount paid.90 A vendee is not entitled to recover for the loss of his bargain, however, even if he would have derived a considerable profit from completion of the transaction. ${ }^{91}$ The policy of the courts in these cases

83. E. g., In re Oscar Nebel Co., 117 F. 2d 326 (3d Cir. 1941) ; Dluge v. Whiteson, 292 Pa. 334, 141 Atl. 230 (1928); Atlantic Tire Rubber Co. v. Southwark Foundry, $289 \mathrm{~Pa}$. 569, 137 Atl. 807 (1927). Contra: Graham v. Lebanon, $240 \mathrm{~Pa} .337,87$ At1. 567 (1913).

84. Cherry Valley Iron Works v. Florence, 64 Fed. 569 (6th Cir. 1894) ; Sabas v. Gregory, 91 Conn. 26, 98 At1. 293 (1916) ; Humphrey v. Sagouspe, 50 Nev. 157, 254 Pac. 1074 (1927).

85. See Ist re Oscar Nebel Co., 117 F. 2d 326, 328 (3d Cir: 1941) ; Dluge v. Whiteson, 292 Pa. 334, 335, 141 At1. 230, 231 (1928).

86. Dluge v. Whiteson, supra note 85.

87. See Patterson, Restitution for Benefits Conferred by Party in Default ander Contract in N. Y. Law Revision ComM'N ReP. 195, 232 (1942).

88. PA. Srat. AnN., tit. 69, $\$ 454,456$ (Purdon, 1931).

89. Section 454 provides for compulsory resale of the goods by the seller. Section 456 provides for return to the buyer of the amount in excess of expense of resale and the seller's damages. No Pennsylvania case decided under $\$ 456$ has been found.

90. E. g., Moser v. Jacob Brown Bldg. \& Loan Ass'n, 320 Pa. 371, 182 At1. 531 (1936); McĆlenachan v. Malis, 310 Pa. 99, 164 At1. 780 (1933); Klee v. Silver, 88 Pa. Super. 318 (1926).

91. Kargiathy v. Provident Trust Co., 338 Pa. 358, 12 A. $2 d 11$ (1940) ; Rineer v. Collins, $156 \mathrm{~Pa}$. 342, 27 Atl. 28 (1893); Hertzog v. Hertzog, $34 \mathrm{~Pa} .418$ (1859); Bitner v. Brough, $11 \mathrm{~Pa}$. 127 (1849). Recovery for loss of bargain is allowed in case there is collusion or bad faith. Seidleck v. Bradley, 293 Pa. 379, 142 Atl. 914 (1928); McDowell v. Oyer, $21 \mathrm{~Pa} .417$ (1853). 
is to put the parties back where they were at the time of making the contract, rather than to compensate the purchaser for loss. ${ }^{82}$

In contradistinction, if the vendee defaults after making payments on the purchase price of a piece of real estate, he cannot rescind and recover from the vendor what he has paid. ${ }^{93}$ This is so, provided the vendor was ready and willing to perform, even though the vendee would not have been able to compel performance of the agreement.94 Once again the reason given for denying recovery is that one guilty of a breach should never be allowed to profit by his wrong.95 Whether the money paid by the vendee is an advance on the purchase price, or a deposit as earnest money, or a sum which the contract provides should be forfeited as liquidated damages in case of breach, the vendee who has defaulted while the vendor stood ready and able to perform is denied recovery. ${ }^{96}$ Even the fact that the vendor resold the property and received more than he would had plaintiff performed, does not render the vendor liable to account to the vendee for the latter's partial payments. ${ }^{97}$ In some cases where plaintiff's forfeiture was deemed too great, the courts have found that the vendor "waived" certain provisions of the contract,98 or that he exercised the option provided in the contract to treat the contract as void and confess judgment in ejectment against the vendee. ${ }^{99}$ As was observed in the cases of sales of goods, in many realty cases the money forfeited by the plaintiff is less than the damages which the vendor suffered through the plaintiff's refusal to complete the contract. The amount advanced by the vendee often is small, and the seller's damages are not susceptible of objective appraisal, so that retention of the buyer's payment may fairly be regarded as liquidated damages. ${ }^{100}$ In these factual situations, no unjust enrichment or forfeiture results from the courts' refusal to permit one in default to recover, but quasi contractual principles are violated if a defaulting plaintiff is denied recovery of the amount by which his payments exceed the loss suffered by defendant.

92. This is said to be an outgrowth of solicitude for innocent vendors who, because of the unsettled state of titles in early times, would be taking a great risk in entering into an executory contract for the sale of real estate if the vendee were allowed to have a jury speculate as to the actual value of the land over and above the contract price. See Note, 48 A. L. R. 12,13 (1927).

93. Wasserman v. Steinman, 304 Pa. 150, 155 Atl. 302 (1931) (contract for sale of land for $\$ 175,000$; plaintiff put $\$ 5,500$ in deposit); Sanders v. Brock, $230 \mathrm{~Pa} .609$, 79 Atl. 712 (1911) (sale of building for $\$ 104,000 ; \$ 2,000$ in deposit); Boyd v. McCullough, $137 \mathrm{~Pa} .7,20$ Atl. 630 (1890) (sale of land for $\$ 1,350$; buyer paid $\$ 811$ ); Hathaway v. Hoge, 1 Sadler 119, 1 Atl. 392 (Pa. 1885) (sale of land; buyer paid over half of the contract price); Shamlian v. Waxman, 80 Pa. Super. 73 (1922) (sale of city property for $\$ 18,000$; buyer paid $\$ 1,000)$; Lichetti v. Conway, $44 \mathrm{~Pa}$. Super. 71 (1910) (sale of city property for $\$ 8,000$ subject to ground rent of $\$ 25,000$; buyer paid $\$ 500)$. See Restatement, Contracts $\$ 357$ (1932); 3 WinLIston, Contracts $\$ 791$; Corbin, Right of a Defaulting Vendee to Restitution of Installment Paid, 40 YALE L. J. 1013 (1931).

94. Hathaway v. Hoge, stpra note 93 ; Power v. North, 15 S. \& R. 12 (Pa. 1826).

95. See the opinion in Boyd v. McCullough, $137 \mathrm{~Pa} .7,20$ Atl. 630 (1890).

96. Wasserman v. Steinman, $304 \mathrm{~Pa}$. 150, 155 At1. 302 (1931) (contract provided for forfeiture in case of breach); Sanders v. Brock, $230 \mathrm{~Pa} .609,79$ Atl. 772 (1911) (advance on purchase price); Shamlian v. Waxman, $80 \mathrm{~Pa}$. Super. 73 (1922) (earnest money to be forfeited in case of breach).

97. Sanders v. Brock, supra note 96; cf. Zierdt v. Keal, 98 Pa. Super. 604 (1930).

98. Moser v. Jacob Brown Bldg. \& Loan Ass'n, 320 Pa. 371, 182 At1. 531 (1936);

Wolson v. Freihofer, 84 Pa. Super. 561 (1925); Lowenstein v. Armstrong, $27 \mathrm{~Pa}$. Super. 543 (1905).

99. Howard v. Stillwagon, 232 Pa. 625, 81 Atl. 807 (1911).

100. See Corbin, Right of a Defaulting Vendee to Restitution of Installment Paid, 40 YALE L. J. 1013 (1931). 


\section{CONCLUSTON}

An analysis of the Pennsylvania cases shows that the rights and remedies of a plaintiff who has failed to perform his contractual obligations are at best uncertain and inadequate. Generally he has been denied recovery of the benefits he has conferred upon the other party by his partial performance. The law of quasi contract, which seeks to compensate for actual loss suffered through breach, while preventing unjust enrichment or forfeiture, has played very little part in the decisions and has seldom been the basis for denying or allowing recovery to the defaulting party, either because the declaration contained no quasi contract count, or because the courts preferred to base their holdings on the more orthodox doctrines of contract. The doctrines which developed to provide relief for the more acute cases of forfeiture-substantial performance, severability, and waiver-do not fully answer the problem. They often involve a strained and fictitious construction of the contract, which many courts refuse to make, and they are limited in their application. The doctrine of quasi contract, since it is not concerned with giving effect to the contract, is more flexible and therefore more adequate. Furthermore, to discuss the problem in fictitious terms tends to becloud the real issue; greater clarity would result if the question were dealt with frankly, in terms of rules based on fairness and justice. The element of willfulness of a breach, emphasized in employment and building contracts and entirely disregarded in sales contracts, not only creates inconsistency in the law, but also introduces a concept not properly a part of the law of contract, which aims to compensate and not to punish. While exemplary damages may, under proper circumstances, be allowed to discourage the contract breaker, yet to compel forfeiture where the defendant has received valuable benefits and where no relation exists between the damages caused and the benefits conferred, seems treatment too harsh even for a plaintiff unjustifiably in default. 